\title{
Sinergy between drugs and devices in the fight against sudden cardiac death and heart failure
}

\section{Giuseppe Boriani $\mathbb{D}^{1} *$, Roberto De Ponti ${ }^{2}$, Federico Guerra $\mathbb{( D}^{3}$, Pietro Palmisano $(\mathbb{1}){ }^{4}$, Gabriele Zanotto ${ }^{5}$, Antonio D'Onofrio ${ }^{6}$, and Renato Pietro Ricci ${ }^{7}$}

${ }^{1}$ Cardiology Division, Department of Biomedical, Metabolic and Neural Sciences, University of Modena and Reggio Emilia, Policlinico di Modena, Largo del Pozzo 71, 41121 Modena, Italy; ${ }^{2}$ Cardiovascular Department, Circolo Hospital, Università degli Studi dell'Insubria, Via Ravasi, 2, 21100 Varese, Italy; ${ }^{3}$ Cardiology and Arrhythmology Clinic, Marche Polytechnic University, University Hospital 'Ospedali Riuniti', Via Lodovico Menicucci, 6, 60121 Ancona, Italy; ${ }^{4}$ Cardiology Unit, 'Card. G. Panico' Hospital, Via Papa Pio X, 4, 73039 Tricase, Italy; ${ }^{5}$ UFS Cardiologia Interventistica - Cardiologia Ospedale Mater Salutis, Via Carlo Gianella, 1, 37045 Legnago, Italy; ${ }^{6}$ Unità Operativa di Elettrofisiologia, Studio e Terapia delle Aritmie, Azienda Ospedaliera dei Colli - Monaldi, Via Leonardo Bianchi, 80131, Naples, Italy; and ${ }^{7}$ Centro CardioAritmologico, via Alessandro Poerio 91 , 00152, Roma, Italy

Received 14 May 2020; revised 28 June 2020; editorial decision 16 July 2020; accepted 17 July 2020; online publish-ahead-of-print 16 December 2020

\begin{abstract}
The impact of sudden cardiac death (SCD) in heart failure (HF) patients is important and prevention of SCD is a reasonable and clinically justified endpoint if associated with a reduction in all-cause mortality.

According to literature, in HF with reduced ejection fraction, only three classes of agents were found effective in reducing SCD and all-cause mortality: beta-blockers, mineralcorticoid receptor antagonists and, more recently, angiotensin-receptor neprilysin-inhibitors. In the PARADIGM trial that tested sacubitril/valsartan vs. enalapril, the $20 \%$ relative risk reduction in cardiovascular deaths obtained with sacubitril/valsartan was attributable to reductions in the incidence of both SCD and death due to HF worsening and this effect can be added to the known positive effect of implantable cardioverter-defibrillators in appropriately selected patients.

In order to maximize the implementation of all the available treatments, patients with HF should be included in virtuous networks with a dialogue between all the physician involved, with commitment by all these physicians for appropriate decision-making on application of pharmacological and device treatments according to available evidence, as well as commitment for drug titration before and after device implant, taking advantage from remote monitoring, and with the safety of back up device therapy when indicated. There are potential synergistic effects of drug therapy, with all the therapies acting on neuro-hormonal and sympathetic activation, but specifically with sacubitril/valsartan, and device therapy, in particular cardiac resynchronization therapy, with added incremental benefits on positive cardiac remodelling, prevention of $\mathrm{HF}$ progression, and prevention of ventricular tachyarrhythmias.
\end{abstract}

Keywords Beta-blockers - Heart failure - Mortality • Mineralcorticoid receptor antagonists • Remote monitoring • Sacubitril/valsartan $\bullet$ Sudden cardiac death

\section{Introduction}

Sudden cardiac death (SCD), defined as an unexpected death from cardiac, causes following sudden cardiac arrest occurring within 1 $h$ of the onset of acute symptoms continues to represent an important clinical challenge for contemporary cardiology in view of the variety of clinical conditions that may induce a risk of SCD and of the many pathophysiological factors and mechanisms that may lead to ventricular fibrillation, asystole or pulseless electrical activity. ${ }^{1}$

* Corresponding author. Tel: +39059 4225836, Email: giuseppe.boriani@unimore.it

Published on behalf of the European Society of Cardiology. All rights reserved. @ The Author(s) 2020. For permissions, please email: journals.permissions@oup.com. 
In consideration of the complex interactions among the factors involved in the arrhythmogenesis of SCD, including genetic factors and the variable anatomical and functional myocardial substrates, as well as the role of potential triggers, various approaches can be considered for improving survival through a reduction of SCD (Figure 1). ${ }^{2,3}$

\section{Sudden cardiac death: epidemiology and impact in heart failure}

Despite the reduction in cardiovascular mortality that occurred in the last 20 years in western high-income countries as a result of improvement in prevention and care of ischaemic heart disease and heart failure (HF), ${ }^{4}$ cardiovascular diseases remain the primary cause of mortality in Europe and North America, with SCD accounting for $\sim 25 \%$ of the deaths due to cardiovascular diseases. ${ }^{3}$

The distribution of cases of SCD and the risk in absolute and relative terms have great variations moving from the general population to so-called 'high-risk groups' as shown in Figure 2 and this constitutes the basis for the different strategies promoted for reducing SCD. ${ }^{1,3}$

The overall incidence of SCD in an unselected adult population is 1-2 per 1000 per year, ${ }^{1,3}$ but it is possible to identify, on the basis of clinical factors, some subgroups of patients at higher relative risk of SCD, for whom the incidence of SCD events at 1 year may be at least 10 -fold greater than in the general population. These subgroups of patients at high risk have been evaluated in randomized clinical trials with the aim to assess the risk and cost-benefit ratio of a series of pharmacological and non-pharmacological treatments such as betablockers, amiodarone, or other antiarrhythmic agents, drugs for HF or implantable cardioverter-defibrillators (ICDs) and cardiac resynchronization therapy defibrillator (CRTD) devices. Patients with coronary artery disease and previous myocardial infarctions associated with left ventricular dysfunction as well as patients with HF with systolic dysfunction belong to subgroups at high risk of SCD, together with patients who already experienced a life-threatening ventricular tachyarrhythmia or a cardiac arrest. ${ }^{5}$

The impact of SCD in HF patients is important since up to $50 \%$ of the deaths occurring in patients with systolic HF are sudden and unexpected, with HF associated with a risk of SCD six to nine times

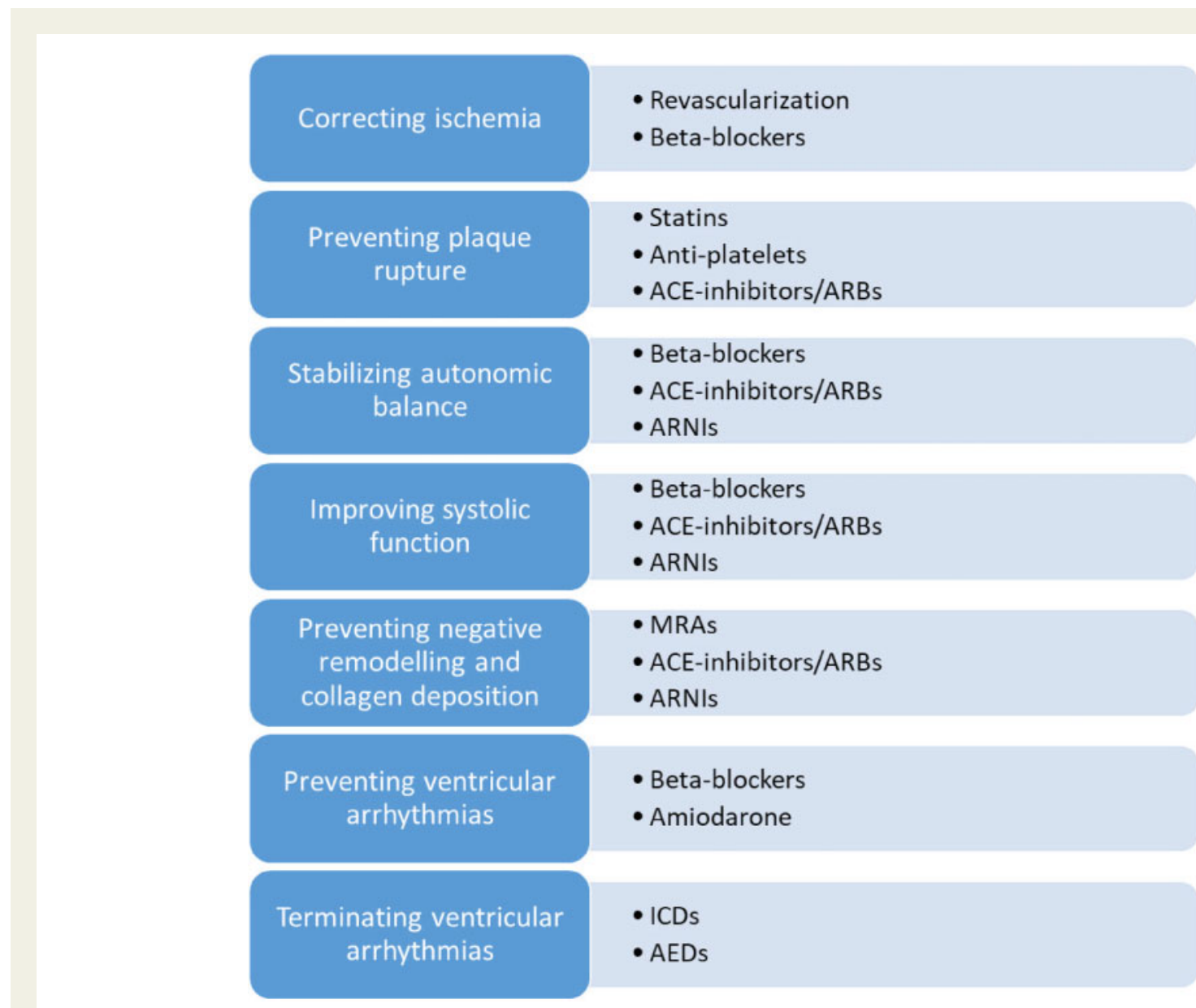

Figure I Treatments to reduce sudden cardiac death by effecting the cardiac substrate or the ventricular arrhythmogenicity. ACE, angiotensinconverting enzyme; AED, automated external defibrillator; ARB, angiotensin-receptor blocker; ARNI, angiotensin-receptor neprilysin inhibitor; ICD, implantable cardioverter-defibrillator; MRA, mineralocorticoid receptor antagonist. 


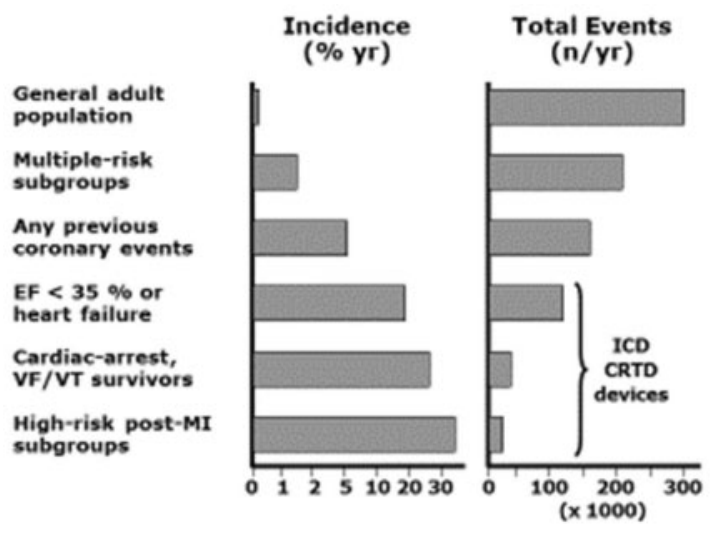

Figure 2 The epidemiology of SCD, with a variable risk of SCD according to patient subgroups in terms of incidence per year (left panel) and total number of events per year (right panel). The categories of patients who are potential candidates for device therapy are indicated (modified from Ref. ${ }^{1}$ ). CRTD, cardiac resynchronization therapy defibrillator; ICD, implantable cardioverter-defibrillator.

higher than the rate of SCD in the general population. ${ }^{3}$ It is noteworthy that in the Metoprolol CR/XL Randomised Intervention Trial in Congestive Heart Failure (MERIT-HF), the proportion of deaths that resulted from SCD was proportionally higher in lower NYHA (New York Heart Association) functional classes. In fact, in NYHA class II, III, and IV patients, the proportion of SCD was $64 \%, 57 \%$, and $33 \%$, respectively, whereas 1 -year absolute risk (cumulative incidence) of SCD was $4 \%, 6 \%$, and $6 \%$, respectively. ${ }^{6}$ This observation is important since indicates that SCD may occur in patients with relatively preserved functional capacities and in whom the outcome in terms of HF-related risk of death is favourable.

The chain of events and the mechanisms leading to SCD include ventricular tachyarrhythmias, and, less frequently and usually in more compromised patients, bradyarrhythmias, asystole, or pulseless electrical activity, although the prediction in an individual patient is often uncertain. The uncertainty is also related to the concept of SCD, an entity which per se is characterized by a terminal event following a sequence of events, while it is not characterized by a single mechanism. A series of pathophysiological mechanisms (atherothrombosis leading to acute ischaemia, neuro-hormonal activation, electrolyte imbalances, etc.) may act as acute triggers, although the common result is an acute electrical or mechanical failure in remodelled and fibrotic ventricles. ${ }^{7}$ However, also genetic factors may play an important role and especially in patients with preserved or midrange left ventricular ejection fraction (LVEF) their role may become predominant for risk characterization and decision-making (Priori et al., Boriani et al., and Zegkos et al. ${ }^{3}$ ).

\section{Treatment of heart failure: goals of treatments}

The fundamental objectives for HF therapy are improving symptoms, functional capacity and quality of life, slowing disease progression, decreasing the need for hospitalization, and decreasing associated mortality. ${ }^{10}$ Within the clinical scenario of HF, there are patients with preserved or reduced LVEF, but only for the latter significant results on outcomes have been demonstrated according to the rules of evidence-based medicine. Indeed, to date, no randomized trial has demonstrated a positive impact on mortality of any drug treatment in patients with $\mathrm{HF}$ and preserved LVEF. ${ }^{11}$

In the general approach to HF with reduced LVEF prevention of SCD is a reasonable and clinically justified endpoint if associated with a reduction in all-cause mortality, thus avoiding a simple 'conversion' in the mode of death. Therefore, in the evaluation of the impact of pharmacological and non-pharmacological treatments, the impact on SCD will always be considered in parallel with the impact on allcause mortality. This approach should be applied to both traditional pharmacological treatments and to the many treatments that were proposed recently and whose validation requires the typical approach of evidence-based medicine. $^{12}$

\section{Impact of traditional drugs for heart failure on sudden cardiac death}

Antiarrhythmic agents, also including amiodarone, have no role in reducing $\mathrm{SCD} .^{2}$ In particular, amiodarone was investigated in SCD$\mathrm{HeFT}$, a trial on the role of ICDs in primary prevention of SCD in HF and no significant improvement in survival in the amiodarone arm vs. the placebo arm of the SCD-HeFT emerged. ${ }^{13}$

A series of pharmacological treatments for HF have been tested in randomized controlled trials with regard to the impact on all-cause mortality, SCD, and other outcomes and the results are reported in detail in Supplementary material online, Table S1.

Beta-blockers are a well-established component of optimized medical treatment for HF and their effects include an improvement in left ventricular structure and function (by decreasing ventricular size and increasing LVEF) as well as an important role in the prevention of arrhythmic events. Several trials have shown that beta-blockers reduce the risk of hospitalizations and death in HF patients. In a metaanalysis of all randomized controlled trials examining the use of betablockers vs. placebo/control for the prevention of SCD in $\mathrm{HF}$ patients beta-blockers result to reduce the risk of SCD by $31 \%$, cardiovascular death by $29 \%$, and all-cause mortality by $33 \% .{ }^{14}$ Despite this substantial benefit, a residual risk of SCD persists during long-term treatment with beta-blockers, thus suggesting the need for additional preventive measures.

In a meta-analysis of published literature, mineralocorticoid receptor antagonists, also called aldosterone antagonists, appeared effective with a $19 \%$ risk reduction for SCD, as well as, with the same amount, for all-cause mortality. ${ }^{15}$

A series of clinical trials have uniformly shown that angiotensinconverting enzyme (ACE) inhibitors provide survival benefits in patients with congestive HF or myocardial infarction. In a metaanalysis of 15 randomized controlled trials comparing ACE inhibitors with placebo in patients following acute myocardial infarction, ACE inhibitor therapy resulted in a $20 \%$ reduction in the risk of death and an $18 \%$ reduction in cardiovascular death and SCD (odds ratio: 0.80; $95 \% \mathrm{Cl} 0.70,0.92) .{ }^{16}$ However, in the setting of HF, two systematic 
reviews did not find a significant effect of $A C E$ inhibitors on the risk of SCD. ${ }^{17,18}$

There is no evidence in support of a role of angiotensin-receptor blockers (ARBs) on SCD in HF. In a meta-analysis, ARBs compared with placebo had no significant effects on all-cause mortality and compared with ACE inhibitors or in combination vs. ACE inhibitors alone, no significant differences were found in all-cause mortality or SCD. ${ }^{15}$

According to a meta-analysis targeted to assess the effectiveness of pharmacological interventions on SCD and all-cause mortality in $\mathrm{HF}$ with reduced LVEF only three classes of agents were found effective: beta-blockers, mineralcorticoid receptor antagonists (MRA) and more recently, as we will discuss later in this chapter, angiotensinreceptor neprilysin-inhibitors (ARNIs). ${ }^{15}$

Ivabradine was found to reduce the composite of cardiovascular death or hospital admission for worsening HF in patients who had symptomatic HF and an LVEF of $35 \%$ or lower were in sinus rhythm with heart rate 70 b.p.m. or higher. ${ }^{19}$ Ivabradine had a significant effect on pump failure death, which was reduced by $26 \%$, but no significant effect on SCD (Swedberg et al. ${ }^{19}$ ).

Recently, sodium-glucose co-transporter-2 (SGLT2) inhibitors ${ }^{20}$ and vericiguat ${ }^{21}$ were found effective in improving outcomes, with regard to worsening HF or cardiovascular death, but the effect on SCD need further evaluation.

\section{Impact of devices on sudden cardiac death in heart failure: defibrillators and cardiac resynchronization therapy}

The role of ICD therapy as a rescue treatment was first conceived by Dr Michel Mirowski over 40 years ago for secondary SCD prevention in selected patients with documented ventricular tachyarrhythmias. ${ }^{22}$ The first ICD was implanted in 1980 and the approval of Food and Drugs Administration was delivered in 1985 for patients who had survived two episodes of cardiac arrest. Following the first pioneering experiences, two key factors led to a progressive widespread implementation of the use of ICDs in selected patients: the technique of implant in a subcutaneous pectoral pocket, without the need for thoracotomy, and the validation, according to a series of randomized controlled trials that tested the efficacy of ICD in reducing SCD and improving overall survival, not only in the selective field of secondary prevention but also in high-risk patients with left ventricular dysfunction without previous sustained ventricular tachyarrhythmias. ${ }^{13,23-31}$

The main results of the randomized controlled trials on the efficacy of ICDs in improving survival are shown in Table 1. It is noteworthy to stress that the use of all-cause mortality has the main endpoint of most of the trial was a key factor in validating ICD therapy, since the assumption that prevention of arrhythmic death or SCD translates into reduction in all-cause mortality is not always true, as demonstrated in the two trials that evaluated the ICD in the setting of a recent myocardial infarction (IRIS and DINAMIT). ${ }^{32,33}$

For all the controlled studies on ICD in SCD prevention, the main criterion for selecting patients at high risk of SCD was the presence of a depressed left ventricular function. The evidence derived from these trials, indicating that ICDs are effective in improving overall survival at 2-5 years in appropriately selected patients with left ventricular dysfunction at high risk of SCD, was the basis for the recommendations for ICD implantation delivered by consensus guidelines. $^{3,10}$ The evidence of the benefit of ICD in non-ischaemic patients has always been less solid than in patients with ischaemic heart disease even if a meta-analysis including CAT, AMIOVERT, DEFINITE, and the non-ischaemic cohort of SCD-HeFT found a statistically significant benefit of ICD therapy on all-cause mortality, with a $26 \%$ relative risk reduction, ${ }^{34}$ and this was the basis for the recommendations of international consensus guidelines. ${ }^{3,10}$ The most recent trial is the DANISH ICD study, ${ }^{35}$ a trial specifically targeted to evaluate the impact of ICD implant in the setting of systolic dysfunction due to non-ischaemic cardiomyopathy. In a follow-up of more than 5.5 years, no survival benefit occurred in the ICD group as compared with usual care in the whole population, but a significant reduction in the risk of all-cause death was found in the subgroup of patients younger than 68 years, with a $36 \%$ relative risk reduction. In interpreting this study, it is important to consider that $58 \%$ of patients received a device for cardiac resynchronization therapy (CRT). A meta-analysis of the efficacy of ICD vs. control in the setting of primary prevention in patients with HF, clearly showed that, even including the DANISH trial, the benefit of ICD on all-cause mortality is confirmed in younger patients (below 65-70 years) with a relative risk reduction of $32 \%$, with important statistical significance. ${ }^{36}$ The DANISH trial had the merit to explore with a dedicated randomized controlled trial the complex setting of non-ischaemic cardiomyopathy, and although the full picture is not completely clear, we improved our knowledge on how age may influence the effect of a prophylactic ICD on all-cause mortality. Below the age of 65-70 years old implanting an ICD appears to be clinically useful also in nonischaemic cardiomyopathy and is therefore suggested by current guidelines, ${ }^{3,10}$ even if this evidence is mostly derived from subgroup analysis. Since age is only one component of the clinical picture of an individual patient, there is need of improving outcome prediction according to more detailed patient characterization including considerations on renal function, diabetes, other comorbidities, and functional status. ${ }^{37,38}$

Device therapy for SCD prevention experienced a substantial improvement with the clinical validation of CRT, initially found effective in patients with moderate to severe HF, and more recently also in mild HF, with clinically important benefits, as shown by the trials shown in Table 2. ${ }^{30,31,39-47}$

According to these trials, use of CRT in appropriately selected patients is associated with significant improvement in overall survival, as well as provides favourable effects in terms of quality of life, exercise capacity and is able to significantly reduce hospitalizations due to $\mathrm{HF}^{48}$

Unfortunately, no one trial with an adequate statistical power compared the use of CRT with and without defibrillation capability, and therefore decision-making on individual patients with regard to the choice between CRT with only pacing (CRT-P) or with defibrillating capability (CRT-D) should be based on clinical considerations including patient age, comorbidities, and clinical status. ${ }^{10,48-50}$

According to most recent guidelines, the recommendation for implanting a CRT device in patients in sinus rhythm with moderate to severe HF (NYHA functional class III-IV) (the setting where the efficacy of CRT was initially validated) are the following: CRT is strongly 
Table I Main controlled trials on implantable cardioverter-defibrillators vs. amiodarone or other controls in secondary and primary prevention of sudden cardiac death out of the setting of recent myocardial infarction

\begin{tabular}{|c|c|c|c|c|c|c|}
\hline Study (year) & $\mathbf{N}$ & Comparison & $\begin{array}{l}\text { Follow-up } \\
\text { (months) }\end{array}$ & Endpoints & $P$-value & $\mathbf{R R R}$ \\
\hline \multicolumn{7}{|l|}{ Secondary prevention trials } \\
\hline $\begin{array}{l}\text { AVID: Antiarrhythmics Versus Implantable } \\
\text { Defibrillators (1997) }{ }^{19}\end{array}$ & 1016 & $\begin{array}{l}\text { ICD vs. AADs (amio- } \\
\text { darone in } 96 \% \text { ) }\end{array}$ & 18 & All-cause death & $<0.02$ & $31 \%$ \\
\hline CIDS: Canadian Implantable Defibrillator & 659 & ICD vs. amiodarone & 36 & All-cause death & 0.142 & $20 \%$ \\
\hline Study $(2000)^{21}$ & & & & Arrhythmic death & 0.094 & $33 \%$ \\
\hline $\begin{array}{l}\text { CASH: Cardiac Arrest Study Hamburg } \\
\qquad(2000)^{22}\end{array}$ & 288 & $\begin{array}{l}\text { ICD vs. amiodarone, } \\
\text { propafenone or } \\
\text { metoprolol }\end{array}$ & 57 & All-cause death & 0.081 & $23 \%$ \\
\hline \multirow[t]{3}{*}{ Meta-analysis AVID, CASH, CIDS $(2000)^{23}$} & 1866 & ICD vs. amiodarone & 28 & All-cause death & $<0.001$ & $27 \%$ \\
\hline & & & & Arrhythmic death & $<0.001$ & $51 \%$ \\
\hline & & & & Non-arrhythmic death & NS & $7 \%$ \\
\hline \multicolumn{7}{|l|}{ Primary prevention trials } \\
\hline $\begin{array}{l}\text { MADIT: Multicenter Automatic Defibrillator } \\
\text { Implantation Trial (1996) }\end{array}$ & 196 & ICD vs. control & 27 & All-cause death & 0.009 & $54 \%$ \\
\hline \multirow[t]{4}{*}{$\begin{array}{l}\text { MUSTT: Multicenter Unsustained } \\
\text { Tachycardia Trial (1999) })^{20}\end{array}$} & 704 & $\begin{array}{l}\text { AADs or ICD (guided } \\
\text { by EPS) vs. }\end{array}$ & 39 & $\begin{array}{l}\text { Cardiac arrest or } \\
\text { arrhythmic death }\end{array}$ & 0.04 & $27 \%$ \\
\hline & & controllCD vs. & & All-cause death & 0.06 & $20 \%$ \\
\hline & & AADs & & $\begin{array}{l}\text { Cardiac arrest or } \\
\text { arrhythmic death }\end{array}$ & $<0.001$ & $76 \%$ \\
\hline & & & & All-cause death & $<0.001$ & $60 \%$ \\
\hline $\begin{array}{l}\text { MADIT II: Multicenter Automatic } \\
\text { Defibrillator Implantation Trial II }(2002)^{24}\end{array}$ & 1232 & ICD vs. control & 20 & All-cause death & 0.016 & $31 \%$ \\
\hline $\begin{array}{l}\text { COMPANION: Comparison of Medical } \\
\text { Therapy, Pacing, and Defibrillation in }\end{array}$ & 1634 & CRT-D vs. control & 16 & $\begin{array}{l}\text { All-cause death or } \\
\text { hospitalization }\end{array}$ & 0.01 & $20 \%$ \\
\hline Heart Failure Trial $(2004)^{25}$ & & & & All-cause death & 0.003 & $36 \%$ \\
\hline \multirow[t]{2}{*}{$\begin{array}{l}\text { SCD-HeFT: Sudden Cardiac Death in Heart } \\
\text { Failure Trial (2004) }\end{array}$} & 2521 & $\begin{array}{l}\text { ICD vs. amiodarone } \\
\text { vs. placebo }\end{array}$ & 45.5 & $\begin{array}{l}\text { All-cause death (ICD } \\
\text { vs. placebo) }\end{array}$ & 0.007 & $23 \%$ \\
\hline & & & & $\begin{array}{l}\text { All-cause death (amio- } \\
\text { darone vs. placebo) }\end{array}$ & NS & $-6 \%$ \\
\hline $\begin{array}{l}\text { MADIT-CRT: Multicenter Automatic } \\
\text { Defibrillator Implantation Trial - Cardiac }\end{array}$ & 1820 & ICD vs. CRT-D & 54 & $\begin{array}{l}\text { All-cause death or HF } \\
\text { event }\end{array}$ & 0.001 & $36 \%$ \\
\hline Resynchronization Therapy $(2009)^{26}$ & & & & HF event & $<0.001$ & $41 \%$ \\
\hline $\begin{array}{l}\text { DANISH ICD: Danish Study to Assess the } \\
\text { Efficacy of ICDs in Patients with Non-is- } \\
\text { chaemic Systolic Heart Failure on } \\
\text { Mortality }(2016)^{29}\end{array}$ & 1116 & $\begin{array}{l}\text { ICD vs. control (CRT- } \\
\text { D in } 58 \%)\end{array}$ & 67.6 & All-cause death & 0.28 & $13 \%^{\mathrm{a}}$ \\
\hline
\end{tabular}

AADs, anti-arrhythmic drugs; Cl, confidence interval; CRT-D, cardiac resynchronization therapy-defibrillator; EPS, electrophysiologic study; HF, heart failure; HR, hazard ratio; ICD, implantable cardioverter-defibrillator; RRR, relative risk reduction.

${ }^{a}$ Hazard ratio 0.87 (95\% Cl 0.68-1.12; $\left.P=0.28\right)$ for ICD vs control in the whole cohort, but among patients $<68$ years $\mathrm{HR} 0.64(95 \% \mathrm{Cl} 0.45-0.90 ; P=0.01)$.

recommended in case of left bundle branch block (LBBB) with QRS duration $>150 \mathrm{~ms}$, while a lower strength of recommendations is released when QRS duration is between 130 and $150 \mathrm{~ms}$, especially if not associated with LBBB. ${ }^{48}$

Moreover, according to guidelines, device therapy for primary prevention of SCD is indicated if LVEF remains reduced, i.e. $\leq 35 \%$, after at least 3 months of optimal medical therapy for HF with agents acting on sympathetic and neuro-hormonal activation such as beta-blockers, ACE inhibitors, ARBs, and MRA. ${ }^{10,48}$ In view of the period of time when ICD trials were conducted, it is clear that they do not reflect the evolution of pharmacological and interventional treatments occurred in the last years, but on the other hand, it will be questionable, in ethical terms, to perform new trials enrolling patients from current daily practice, with randomization of patients at high risk of SCD to ICD vs. no-ICD treatment. Moreover, with all the limitations of non-controlled studies, at least two large-scale prospective registries that evaluated prophylactic ICD implant in HF patients using propensity score matching found a lower long-term mortality 


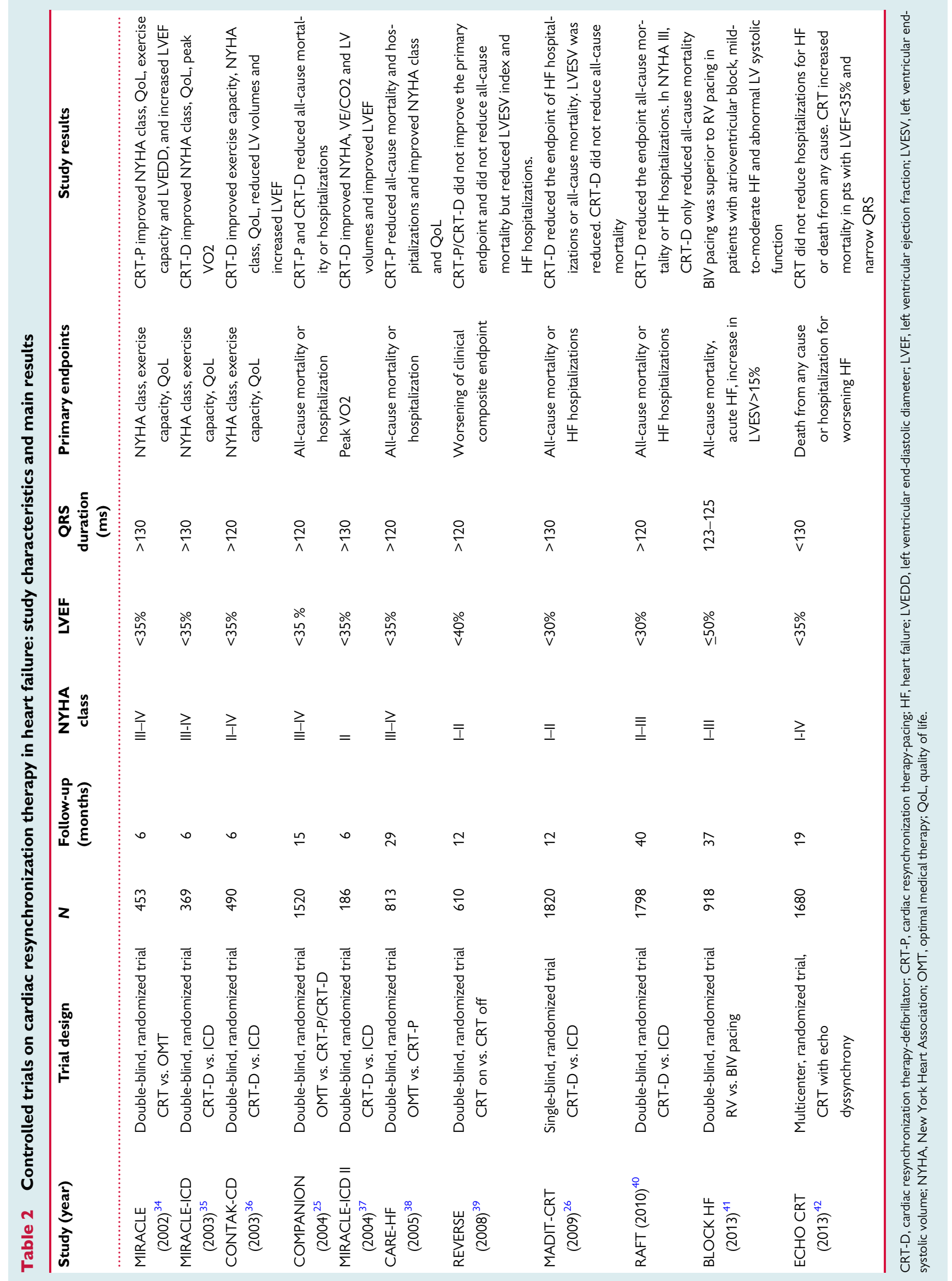




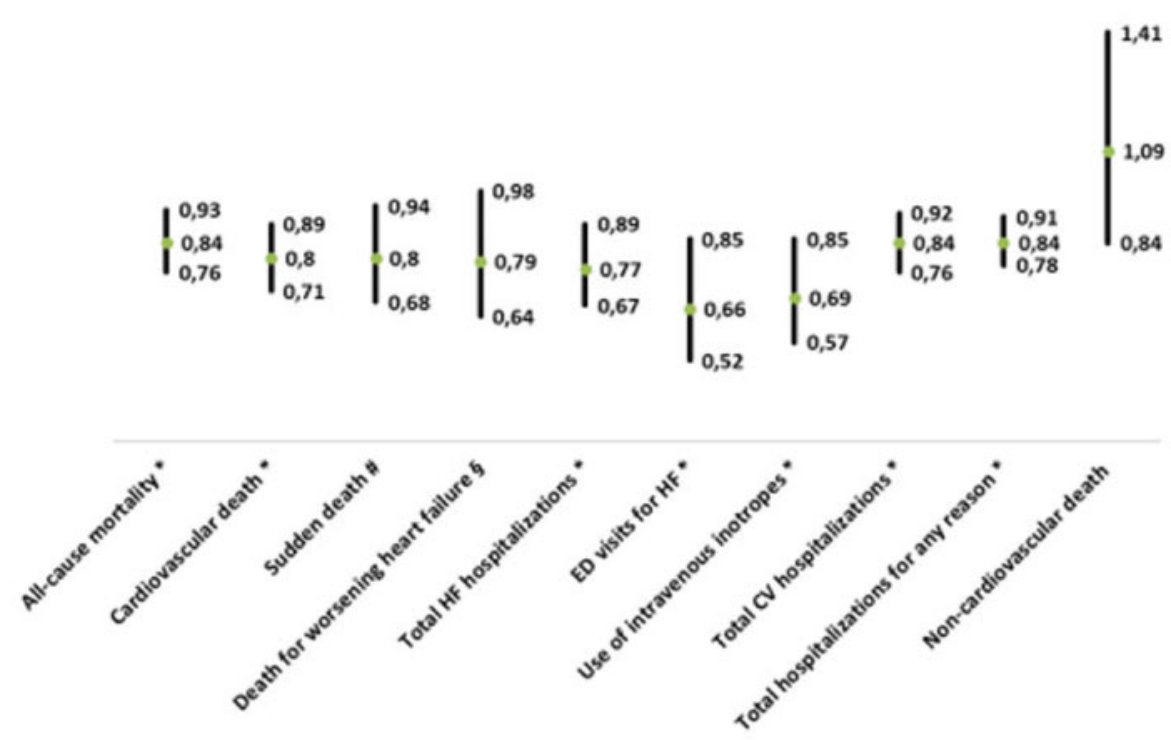

Legend: ^ $p<0.001 ; \# p=0.008 ; \S p=0.034 ; \wedge p=0.017$

Figure 3 Effects of sacubitril/valsartan vs. enalapril on a series of clinical outcomes in the PARADIGM-HF trial. Data are reported as hazard or rate ratios and $95 \%$ confidence intervals. From Refs. ${ }^{56-58}$. CV, cardiovascular; ED, emergency department; HF, heart failure.

CV death or HF hospitalization $P_{\text {int }}=0.561$

$$
\left.\begin{array}{l|l}
0,87 \\
0,79 \\
0,72
\end{array} \quad\right|_{0,67} ^{1,04}
$$

CV death

$P_{\text {lint }}=0.912$

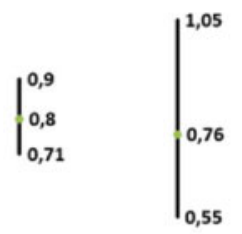

No ICD/CRTD Yes ICD/CRTD

Figure 4 Data from PARADIGM-HF trial on the effect of sacubitril/valsartan vs. enalapril in the subgroups without $(n=7156)$ and with defibrillator therapy back-up (with an ICD or CRTD device) $(n=1243) .{ }^{62}$ No significant interaction was found $\left(P_{\text {int }}\right.$ was not significant). CRTD, cardiac resynchronization therapy defibrillator; $C V$, cardiovascular; HF, heart failure; ICD, implantable cardioverterdefibrillator.

in ICD patients vs. no-ICD patients, ${ }^{51,52}$ together with an underuse of ICD therapy. ${ }^{51}$

The wearable cardioverter defibrillator is a non-invasive option that has been used in patients at risk of SCD not eligible for an ICD. Moreover, the wearable ICD has been proposed for short-term use in patients with an high risk of ventricular tachyarrhythmias that is considered to be transient with some possibility to diminish over time (i.e. severe myocarditis or severe coronary disease prior to revascularization) or when implant of a transvenous ICD is contraindicated (i.e. infection requiring ICD system removal). Data on safety of the wearable defibrillator have been collected in a prospective registry (WERIT-II) and during a median duration period of 90 days the rate of sustained ventricular tachyarrhythmias was 3\% among patients with ischaemic cardiomyopathy and $1 \%$ among nonischaemic patients $(P=0.02) .{ }^{53}$

Recently, the role of the wearable cardioverter defibrillator was tested in a randomized controlled trial, the VEST study that randomized 2302 patients with recent myocardial infarction and LVEF $<35 \%$ to a wearable defibrillator or watchful waiting. No reduction in the primary endpoint of SCD or 90-day arrhythmic death, while the reduction in total mortality found in the group with a wearable defibrillator became insignificant after correction with various approaches of the multiplicity of tests. ${ }^{54}$ In this trial, problems of adherence to wearing the defibrillator complicated the ability to demonstrate a clinical benefit and only the on-treatment and per-protocol analyses showed a benefit in patients selected for high compliance to the wearable defibrillator. ${ }^{55}$

\section{Sacubitril/valsartan: impact on cardiovascular mortality and on sudden cardiac death}

One of the most important innovation of recent years is the evidence of benefit of ARNIs and specifically of sacubitril/valsartan, at present the only agent available for clinical practice. The use of sacubitril/valsartan has been validated by the PARADIGM trial. In this 
prospective randomized trial, 8442 patients with chronic HF, NYHA functional class II-IV, with LVEF $\leq 35 \%$ ( $\leq 40 \%$ for the first of the 3 years of patient enrolment), were evaluated to compare the effect of sacubitril/valsartan 97/103 mg b.i.d. compared with enalapril $10 \mathrm{mg}$ b.i.d., in addition to conventional treatment, in delaying time to first occurrence of either cardiovascular death or HF hospitalization. ${ }^{56}$ Sacubitril/valsartan treatment was associated to a $20 \%$ reduction of the primary endpoint, with a $21 \%$ reduction of HF hospitalizations and $20 \%$ reduction of death for cardiovascular causes. ${ }^{56}$ Over $80 \%$ of deaths in PARADIGM-HF had a cardiovascular cause, of which $45 \%$ were due to SCD. Among the causes of death observed in PARADIGM-HF, SCD accounted for $35.2 \%$ of all the deaths occurred in the sacubitril/valsartan arm and for $37.2 \%$ of all the deaths occurred in the enalapril arm. ${ }^{57}$

A complete picture of the benefits highlighted by the PARADIGM$\mathrm{HF}$ trial is shown in Figure 3, where a series of endpoint of high clinical significance resulted favourably and significantly improved by sacubitril/valsartan compared with enalapril. As expected, noncardiovascular mortality was not affected, thus stressing the need for multidisciplinary interventions on the most important comorbidities, related to diabetes, kidney function, etc. ${ }^{58-61}$

\section{Sacubitril/valsartan in patients with defibrillators or cardiac resynchronization therapy: the potential for a synergistic effect}

In the PARADIGM-HF trial, sacubitril/valsartan therapy was associated to a significant $20 \%$ reduction of SCD when compared with enalapril therapy and the reduction of overall mortality and SCD was observed both in patients with and without ICD or CRT-D (Figure 4). ${ }^{62}$ Unexpectedly, considering that all patients enrolled in the PARADIGM-HF trial had an LVEF $\leq 35 \%$, only $15 \%$ of them had an implanted ICD and 7\% a CRT device. Of note, both survival curves for death for cardiovascular causes and for SCD began to diverge early in patient without ICD/CRT-D and late (after 2 years) in those with ICD/CRT-D. ${ }^{62}$

The benefits of sacubitril/valsartan in SCD reduction led to investigate in detail the interaction between ARNI e device therapy in patients with HF. De Diego et al. ${ }^{63}$ investigated the effect of angiotensin-neprilysin inhibition on ventricular arrhythmias compared with angiotensin inhibition in $120 \mathrm{HF}$ with reduced LVEF patients with an ICD and remote monitoring. Appropriate shocks significantly decreased in the sacubitril valsartan arm from $6.7 \%$ to $0.8 \%$. Furthermore, sustained and non-sustained ventricular tachycardia episodes significantly decreased. No differences were observed in atrial fibrillation incidence. Similar results have been reported by Martens et al. ${ }^{64}$ Possible explanation for the antiarrhythmic effects of sacubitril/valsartan include the increase of beneficial natriuretic peptides leading to diuresis, vasodilatation, decrease of sympathetic tone, and of aldosterone levels. Furthermore, cardiac fibrosis suppression and structural remodelling as well as wall stress reduction may play a role. ${ }^{63-66}$

Another potential synergistic effect of drug therapy with sacubitril/ valsartan and device therapy, in particular CRT, is the incremental benefits on positive cardiac remodelling and prevention of HF progression. However, data from registries have shown that up to $30 \%$ of CRT patients do not receive guideline-directed optimal medical therapy. ${ }^{67}$ As a matter of fact, it has been clearly demonstrated that optimal medical therapy is associated with better survival in patients with implanted ICD and CRT. ${ }^{68,69}$ Furthermore, continuous remote monitoring of patients with implanted devices offers a unique opportunity to early detect HF impairment and to timely optimize medical therapy. $^{70-72}$

\section{Considerations about guideline- adherent medical and device therapy in HF}

- There are good reasons to support a synergistic effect between electrical treatments and guideline-adherent pharmacological therapy, with specific focus on sacubitril/valsartan, the last agent introduced in daily practice. The clinical target should be to implement these treatments in all the patients with a guideline-adherent indication, in order to ensure the most effective treatments for improving outcomes, according to a series of considerations:

- SCD may occur unexpectedly and despite the reduction that can be obtained with sacubitril/valsartan, combined with beta-blockers and MRAs, a residual risk persists and therefore the back-up of ICD therapy for termination of malignant ventricular tachyarrhythmias may ensure the best protection at long term and maximize cardiovascular outcomes for patients who have an indication according to guidelines. ${ }^{3,10}$

- Implant of a device such as ICD, CRT-D, or CRT-P according to guidelines indications should not be postponed beyond the period indicated by guidelines ( 3 months of optimal medical treatment) $)^{3,10}$ and according to national rules for prescribing sacubitril/ valsartan the latter treatment can be implemented either before or after device implant.

- An extension of the period for implementation and titration of beta-blockers, MRAs, ACE inhibitors, ARBs, or sacubitril/valsartan up to 9-12 months, rather than the usual 3 months waiting period, sometimes applied in case of new-onset HF in order to maximize left ventricular remodelling and increase LVEF, implies a small but significant risk of SCD $(2-4 \%)^{73,74}$ that may be particularly dramatic in young patients. Therefore, patients at higher risk of SCD (patients with severe left ventricular dysfunction, patients with non-sustained ventricular tachycardia) and younger patients should be absolutely prioritized for not delaying ICD implant.

- It is absolutely important to titrate beta-blockers, ACE inhibitors, ARBs, or sacubitril/valsartan up to maximum tolerated doses and this process has to be applied both before and after implant of an electrical device, ${ }^{75,76}$ also with the advantage of the back-up of anti-bradycardia pacing provided by electrical devices in case of excessive bradycardia following an attempt of dosage increase for a beta-blocker. ${ }^{77}$

- An improvement in LVEF during long-term follow-up is a frequent finding after implant of an ICD, even above $35 \%$, but it is not associated with lack of appropriate device interventions for malignant ventricular tachyarrhythmias thus suggesting that the risk of ventricular tachyarrhythmias and SCD is modulated by pharmacological treatments, but a residual risk persists, along with 
time, that in appropriate patients may surely benefit from the rescue role of a back-up ICD. ${ }^{78-81}$

- In patients implanted with an ICD or a CRT-D appropriate ICD shocks (especially when clustered into electrical storms) are associated with a significant increase in the subsequent risk of all-cause death $^{82,83}$ and therefore the occurrence of shocks, even if appropriate, should be considered a warning sign of a worsening prognosis. $^{84}$ Implementation of sacubitril/valsartan is in these cases absolutely appropriate in order to implement the favourable effects of this agent on ventricular tachyarrhythmias. ${ }^{63,64,85}$ and maximize the ability to improve outcome as well as quality of life $^{86}$ and ICD electrical atrial parameters. ${ }^{87}$

- The process of reduction of left ventricular volumes, with reversal of left ventricular geometry alterations and with improvement of systolic function occurring in HF after neuro-hormonal blockade (the so-called 'left ventricular reverse remodelling') is a key factor for outcome improvement, also in terms of prevention of $\mathrm{SCD}^{88,89}$ and is more pronounced with $\mathrm{ARNI}$ as compared with $A C E$ inhibitors, thus supporting the rationale for instituting sacubitril/valsartan in all the patients who can be eligible for ARNI treatment. $^{90}$

- CRT is a very effective non-pharmacological treatment in appropriately selected patients, ${ }^{91,92}$ and structural left ventricular reverse remodelling is a key factor in determining the clinical and outcome benefits at long term. ${ }^{93}$

- CRT is primarily indicated in patients with LBBB and the haemodynamic benefit is related to correction of the electro-mechanical associated with the conduction disturbance. It is noteworthy that LBBB-associated remodelling appears to result in a limited reverse remodelling during guideline-adherent pharmacological treatment as compared with non-LBBB patients, thus indicating that in patients with LBBB implant of a CRT device, following implementation of drug treatment for a reasonable period of time, should not be deferred, waiting for an improvement of LVEF induced by pharmacological treatments that has a very limited chance to occur. ${ }^{94}$ Moreover, after implant of a CRT device, there is the possibility of an increase in systolic blood pressure that may allow initiation of drugs that were not tolerated or could not be administered for hypotension before implant, such as sacubitril/valsartan, in line with the concept of additive, if not synergistic effects between CRT and ARNI.

- Remote monitoring offers the possibility to detect signals and measures data from pacemakers, ICD, and other implantable devices. The aim is to detect impending HF decompensation and to consequently take decisions on drug dosages and patients care. Unfortunately, the high expectations of benefit were not confirmed by the randomized studies performed so far. ${ }^{95}$ However, some prospective non-controlled studies recently performed, indicate a positive impact on patient management with the most recent device algorithms able to collect data from multiple sensors, ${ }^{71,96}$ with need to better assess the impact of these technologies through randomized controlled studies for a more detailed assessment.

- The dialogue and synergistic actions and decisions of cardiologists involved in electrophysiology and device therapy and cardiologists dedicated to HF care is important and will continue to be important for future treatments, either pharmacological or nonpharmacological. $^{12}$

- The value of ICD back-up to minimize the residual risk of SCD in patients with an established indication and who are candidate to initiate sacubitril/valsartan is further supported by some data on the initial period of treatment with sacubitril/valsartan. ${ }^{97-99}$ These data are observational and related to case reports or to a collection of pharmacovigilance reports and even if they do not put into question the evidence of benefit of sacubitril/valsartan on SCD at long term, are of interest for considerations on the time course and the determinants of the effect of this agent on arrhythmogenesis and the cardiac substrate. The reverse left ventricular remodelling induced by sacubitril/valsartan may actually be the key mechanism for reducing $\mathrm{SCD}^{7}$ but some months are required for this process to occur, thus with exposure to a residual risk of SCD especially in the first 3 months after treatment initiation. ${ }^{99}$ These data, even if observational, strongly suggest the advantages of a combined use or sacubitril/valsartan and ICD, when indicated according to guidelines, without delaying the device implant, in order to fully achieve the benefits that these two treatments may independently exert, and with the potential for synergistic effects.

\section{Organizational implications for maximizing the implementation of drugs and devices in patients at risk}

In view of the increasing burden of cardiovascular disease and specifically HF, there is need for improving knowledge on treatments for HF and SCD prevention of proven efficacy according to evidencebased medicine, as implemented in consensus guidelines recommendations. General practitioners, internists, physicians involved in $\mathrm{HF}$ care and emergency medicine, as well as electrophysiologists should dialogue and collaborate more strictly, in a perspective of patientcentred care, organizing network for appropriate patient referral both for pharmacological and device therapy. Indeed, it has been reported that in Sweden an important and substantial awareness gap was found through a survey among the medical community, thus explaining the limited referral rates and utilization of device therapy in HF patients. ${ }^{100}$

\section{Conclusions}

In order to maximize the implementation of all the available treatments, either pharmacological or non-pharmacological, patients with HF should be included in virtuous networks with a dialogue between all the physician involved, specifically cardiologists involved in electrophysiology and device therapy and cardiologists dedicated to HF care.

A strict collaboration between specialists is absolutely needed since there are potential synergistic effects between drug therapies acting on neuro-hormonal and sympathetic activation (specifically sacubitril/valsartan) and device therapy, in particular CRT, with benefits in terms of reverse cardiac remodelling, slowing of HF progression and prevention of ventricular tachyarrhythmias.

It is absolutely important to titrate beta-blockers, ACE inhibitors, ARBs, or sacubitril/valsartan up to maximum tolerated doses and this process has to be applied both before and after implant of an electrical device. 
An extension of the period for implementation and titration of beta-blockers, MRAs, ACE inhibitors, ARBs, or sacubitril/valsartan up to 9-12 months, rather than the usual 3 months waiting period, implies a small but significant risk of SCD $(2-4 \%)^{73,74}$ that may be particularly dramatic in young patients. Therefore, patients at higher risk of SCD (patients with severe left ventricular dysfunction, patients with non-sustained ventricular tachycardia) and younger patients should be prioritized for not delaying ICD implant.

\section{Supplementary material}

Supplementary material is available at European Journal of Preventive Cardiology online.

Conflict of interest: F.G. reported speaker's fess of small amount from Boston Scientific and Novartis. G.B. reported speaker's fees of small amount from Boehringer, Boston, Biotronik, Medtronic, out of the submitted work. The other authors declare they have no conflicts of interest.

\section{References}

1. Myerburg RJ, Kessler KM, Castellanos A. Sudden cardiac death: structure, function, and time-dependence of risk. Circulation 1992;85;10-12.

2. Boriani G, Diemberger I, Valzania C, Biffi M, Martignani C, Raschi E, Mantovani V, Ziacchi M, Bertini M, De Ponti F, Branzi A. Role of drugs and devices in patients at risk of sudden cardiac death. Fundam Clinical Pharmacol 2010;24:575-594.

3. Priori SG, Blomström-Lundqvist C, Mazzanti A, Blom N, Borggrefe M, Camm J, Elliott PM, Fitzsimons D, Hatala R, Hindricks G, Kirchhof P, Kjeldsen K, Kuck K-H, Hernandez-Madrid A, Nikolaou N, Norekvål TM, Spaulding C, Van Veldhuisen DJ, Kolh P, Lip GYH Agewall S, Barón-Esquivias G, Boriani G, Budts W, Bueno H, Capodanno D, Carerj S, Crespo-Leiro MG, Czerny M, Deaton C, Dobrev D, Erol C, Galderisi M, Gorenek B, Kriebel T, Lambiase P, Lancellotti P, Lane DA, Lang I, Manolis AJ, Morais J, Moreno J, Piepoli MF, Rutten FH, Sredniawa B, Zamorano JL, Zannad F, Zamorano JL, Aboyans V, Achenbach S, Agewall S, Badimon, Barón-Esquivias G, Baumgartner H, Bax J, Bueno H, Carerj S, Dean V, Erol Ç, D. Fitzsimons D Gaemperli O, Kirchhof P, Kolh P, Lancellotti P, Lip GY, Nihoyannopoulos P, Piepoli MF, Ponikowski P, Roffi M, Torbicki A, Vaz Carneiro A, Windecker S, Piruzyan A, Roithinger FX, Mairesse GH, Goronja B, Shalganov T, Puljevic D, Antoniades L, Kautzner J, Larsen JM, Aboulmaaty M, Kampus P, Hedman A, Kamcevska-Dobrkovic L, Piot O, Etsadashvili K, Eckardt L, Deftereos S, Gellér L, Gizurarson S, Keane D, Haim M, Della Bella, Abdrakhmanov A, Mirrakhimov A, Kalejs O, Ben Lamin H, Marinskis G, Groben L, Sammut M, Raducan A, Chaib A, Tande PM, Lenarczyk R, Morgado FB, R. Vatasescu R, Mikhaylov PEN, Hlivak P, Arenal A, Jensen-Urstad M, Sticherling C, Zeppenfeld K, Chettaoui R, Demir M, Duncan E.. 2015 ESC Guidelines for the management of patients with ventricular arrhythmias and the prevention of sudden cardiac death. Eur Heart J 2015;36:2793-2867.

4. Dendale P, Scherrenberg M, Sivakova O, Frederix I. Prevention: from the cradle to the grave and beyond. Eur J Prev Cardiol 2019;26:507-511.

5. Nichol G, Sayre MR, Guerra F, Poole J. Defibrillation for ventricular fibrillation. J Am Coll Cardiol 2017;70:1496-1509.

6. Hjalmarson A, Goldstein S, Fagerberg B, Wedel F, Waagstein J, Kjekshus J, Wikstrand G, Westergren M, Thimell D, El Allaf J, Vítovec J, Aldershvile M, Halinen R, Dietz KL, Neuhaus A, Jánosi G, Thorgeirsson P Dunselman L, Gullestad J, Kuch J, Herlitz P, Rickenbacher S, Ball S, Gottlieb P, Deedwania G, Vandenhoven I, Nováková S, Danker M, Lundström W, Meyer-Sabellek I, Ball M, Sveinsdottir B, Dorhout A, Hildebrandt I, Szczurko C, Larsson, E, Bucher E, Scott D, Dwyer DG, Julian DL, DeMets K, Chatterjee J, Feyzi S, Lehto P, Kárpáti W, Motz O, Samuelsson JW, Viersma B, Andersson C, Berthe JM, Boutefeu G, Boxho P, Decroly JP, Derbaudrenghien J, Pirlet P, Henry G, Heyndrickx L, Missault M, Nannan P, Timmermans JL, Vachiery W, Van Mieghel JL, Vandenbossche K, Dvorák M, Herold J, Hradec A, Kána P, Petr J, Rybka J, Smíd P, Svítil J, Toman E, Agner O, Amtorp K, Egstrup P, Eliasen CO, Gotzsche P, Hildebrandt A, Johannesen P, Kaiser-Nielsen H, Nielsen PE, Nielsen F, Pedersen J, Rokkedal Nielsen K, Skagen T, Honkanen E, Hussi J, Juvonen $H$, Jääskeläinen J, Rinne T, Salonen D, Andresen H, Berwing Bethge Beythien, Bischoff Bundschu Daniel, Darius Delius, Drude Dingerkus, Dück Eichler, Fach A, Förster Girth, Goss Hahn,
Hambrecht GF, Hauf Heinemann, Hepp Janka, Klocke, Konz B, Krosse Kühlkamp, Lewek B, Lüderitz, Löbe, Maier, Melchior, Müller, Mäurer Nast, Neuhaus Obst, Odemar KE, von Olshausen, Pomykaj KJG, Schmailzl S, Schröder PL, Schwimmbeck M, Sigmund Simon Strasser, Thilo Vöhringer $H$, Völler WW, Wunderlich I, Czuriga M, Hetey A, Katona M, Lengyel A, Nyárádi A, Rednik K, Sándori P, Szabó J, Tarján J, Tenczer S, Timár P, Vályi G, Veress K, Zámolyi B, Öze G, Thorgeirsson G, Thorgeirsson PJLM, Bernink AC, Breder RW, Breedveld PNWM, Breuls JJ, Bucx JH, Cornel PAR, De Milliano PHJM, Dunselman BJB, Hamer NL, Holwerda J, Hoogsteen JCA, Hoorntje JA, Kragten AH, Liem GCM, Linssen HR, Michels AR, Ramdat Misier HJ, Schaafsma P, Sijbring RJT, Taverne LHJ, Van Kempen R, Van Stralen PJ, Van Veldhuisen MJ, Veerhoek CJPJ, Werter JCL, Wesdorp AR, Willems AJAM, Withagen PAG, Zwart R, Bjornerheim M, Dahle K, Dickstein GS, Froland T, Gundersen K, Hofsoy TL, Hole T, Johansen J, Mannsverk P, Nesje TM, Omland C, Sjödin P, Smith HA, Tjonndal O, Vikesdal K, Waage Adamus K, Jaworska P, Kolodziej Z, Kornacewicz-Jach M, KrzemiñskaPakula JW, Piotrowski W, Piwowarska A, Stogowski J, Wodniecki K, Wrabec P, Ahlström S, Ekdahl LO, Hemmingson L, Holmberg B, Lernfelt H, Nilsson B Widgren K, Ångman P, Erne P, Mohacsi R, Polikar H, Schläpfer P, Batin KE, Berkin TS, Callaghan J, Forfar M, Frenneaux RA, Greenbaum M, Maltz D, Murdoch G, Reynolds J, Stephens A, Struthers J, Swan G, Tildesley A, Abbasi P, Alagona J, Alderman M, Alipour JL, Anderson Z, Ansari M, Ashraf BT, Beanblossom S, Bennett D, Benvenuti MR, Berk R, Bhalla SD, Bilazarian, KF, Browne C, MBuchter R, Carlson CJ, Carlson K, Danisa I, Dauber MA, DeWood G, Dennish DM, Denny R, DiBianco PM, Diller M, Dunlap K, Dowd A, Edmiston M, El Shahawy U, Elkayam J, Farnham P, Fenster S, Friedman T, Heywood JP, Galichia M, Geller, JK, Ghali M, Gheorghiade T, Giles R, Gillespe G, Goldberg MC, Goldberg DA Goldscher GP, Gooden M, Goodman L, Goodman J, Gorwit SS, Gottlieb A, Gradman D, Grech T, Hack JH, Hall, MT, Hattenhauer MB, Higginbotham S, Hutchins M, Imburgia BJ, Iteld B, Jackson S, Jafri W, Jauch S, Jennison BH, Kahn W, Kao K, Kaplan R, Karlsberg HL, Kennedy JJ, Kennedy L, Kirkegaard DH, Kraus K, LaBresh L, Lalonde MF, Lesser R, Levites M, Levy RK, Lewis IK, Loh H, Madyoon F, Maislos D, Mann GL, Maurice A, Nisar W, Old JD, Pappas K, Phadke S, Promisloff AM, Rashkow B, Reeves JH, Rosen M, Rotman T, Saleem SV, Savran R, Shah Y, Shalev JG, Shanes M, O'Shaughnessy B, Silverman RM, Steingart L, Swenson K, Syed U, Thadani RD, Thorsen MJ, Tonkon R, Touchon G, Uhl KJ, Vaska SG, Wagner CJ, Weaver RJ, Weiss WJ, Wickemeyer HJ, Willens JR, Wilson $\mathrm{R}$, Wright $\mathrm{L}$, Yellen. Effect of metoprolol $C R / X L$ in chronic heart failure: Metoprolol CR/XL Randomised Intervention Trial in Congestive Heart Failure (MERIT-HF). Lancet 1999;353:2001-2007.

7. Packer M. What causes sudden death in patients with chronic heart failure and a reduced ejection fraction? Eur Heart J 2020;41:1757-1763.

8. Boriani G, Biagini E, Ziacchi M, Malavasi VL, Vitolo M, Talarico M, Mauro E, Gorlato G, Lattanzi G. Cardiolaminopathies from bench to bedside: challenges in clinical decision-making with focus on arrhythmia-related outcomes. Nucleus 2018; 9:442-459.

9. Zegkos T, Panagiotidis T, Parcharidou D, Efthimiadis G. Emerging concepts in arrhythmogenic dilated cardiomyopathy. Heart Fail Rev 2020. doi:10.1007/s10741020-09933-z.

10. Ponikowski P, Voors AA, Anker SD, Bueno H, Cleland JGF, Coats AJS, Falk V, González-Juanatey JRV, Harjola, -P, Jankowska EA, Jessup, M, Linde C, Nihoyannopoulos P, Parissis JT, Pieske B, Riley JP, Rosano GMC, Ruilope LM, Ruschitzka F, Rutten FH, van der Meer P, Filippatos G, McMurray JJV, Aboyans V, Achenbach S, Agewall S, Al-Attar N, Atherton J, Bauersachs J, John Camm A, Carerj S, Ceconi C, Coca A, Elliott P, Erol Ç, Ezekowitz J, Fernández-Golfín C, Fitzsimons D, Guazzi M, Guenoun M, Hasenfuss G, Hindricks G, Hoes AW, lung B, Jaarsma T, Kirchhof P, Knuuti J, Kolh P, Konstantinides S, Lainscak M, Lancellotti P, Lip GYH, Maisano F, Mueller C, Petrie MC, Piepoli MF, Priori SG, Torbicki A, Tsutsui $H$, van Veldhuisen DJ, Windecker S, Yancy C, Zamorano JL, Zamorano JL, Aboyans V, Achenbach S, Agewall S, Badimon L, Barón-Esquivias G, Baumgartner H, Bax JJ, Bueno H, Carerj S, Dean V, Erol C, Fitzsimons D, Gaemperli O, Kirchhof P, Kolh P, Lancellotti P, Lip GYP, Nihoyannopoulos P, Piepoli MF, Ponikowski P, Roffi M, Torbicki A, Vaz Carneiro A, Windecker S, Sisakian HS, Isayev E, Kurlianskaya A, Mullens W, Tokmakova M, Agathangelou P, Melenovsky $V$, Wiggers $H$, Hassanein $M$, Uuetoa $T$, Lommi J, Kostovska ES, Juillière $Y$, Aladashvili A, Luchner A, Chrysohoou C, Nyolczas N, Thorgeirsson G, Marc Weinstein J, Di Lenarda A, Aidargaliyeva N, Bajraktari G, Beishenkulov M, Kamzola G, Abdel-Massih T, Celutkiene J, Noppe S, Cassar A, Vataman E, Abir-Khalil S, van Pol P, Mo R, Straburzynska-Migaj E, Fonseca C, Chioncel O, Shlyakhto E, Otasevic P, Goncalvesová E, Lainscak M, Díaz Molina B, Schaufelberger M, Suter T, Yilmaz MB, Voronkov L, Davies C. 2016 ESC Guidelines for the diagnosis and treatment of acute and chronic heart failure. Eur Heart J 2016;37:2129-2200.

11. Bonsu KO, Arunmanakul P, Chaiyakunapruk N. Pharmacological treatments for heart failure with preserved ejection fraction - a systematic review and indirect comparison. Heart Fail Rev 2018;23:147-156.

12. Seferovic PM, Ponikowski P, Anker SD, Bauersachs J, Chioncel O, Cleland JGF, de Boer RA, Drexel H, Ben Gal T, Hill L, Jaarsma T, Jankowska EA, Anker MS, 
Lainscak M, Lewis BS, McDonagh T, Metra M, Milicic D, Mullens W, Piepoli MF, Rosano G, Ruschitzka F, Volterrani M, Voors AA, Filippatos G, Coats AJS. Clinical practice update on heart failure 2019: pharmacotherapy, procedures, devices and patient management. An expert consensus meeting report of the Heart Failure Association of the European Society of Cardiology. Eur J Heart Fail 2019;21:1169-1186.

13. Bardy GH, Lee KL, Mark DB, Poole JE, Packer DL, Boineau R, Domanski M, Troutman C, Anderson J, Johnson G, McNulty SE, Clapp-Channing N, DavidsonRay LD, Fraulo ES, Fishbein DP, Luceri RM, Ip JH. Amiodarone or an implantable cardioverter-defibrillator for congestive heart failure. N Engl J Med 2005;352: 225-237.

14. Al-Gobari M, Khatib C El, Pillon F, Gueyffier F. Beta-blockers for the prevention of sudden cardiac death in heart failure patients: a meta-analysis of randomized controlled trials. BMC Cardiovasc Disord 2013;13. doi:10.1186/1471-2261-13-52.

15. Al-Gobari M, Al-Aqeel S, Gueyffier F, Burnand B. Effectiveness of drug interventions to prevent sudden cardiac death in patients with heart failure and reduced ejection fraction: an overview of systematic reviews. BMJ Open 2018;8. doi: 10.1136/bmjopen-2017-021108.

16. Domanski MJ, Exner DV., Borkowf CB, Geller NL, Rosenberg Y, Pfeffer MA. Effect of angiotensin converting enzyme inhibition on sudden cardiac death in patients following acute myocardial infarction: a meta-analysis of randomized clinical trials. J Am Coll Cardiol 1999;33:598-604.

17. Garg R, Yusuf S. Overview of randomized trials of angiotensin-converting enzyme inhibitors on mortality and morbidity in patients with heart failure. JAMA J Am Med Assoc 1995;273:1450-1456.

18. Flather MD, Yusuf S, Køber L, Pfeffer M, Hall A, Murray G, Torp-Pedersen C, Ball S, Pogue J, Moyé L, Braunwald E. Long-term ACE-inhibitor therapy in patients with heart failure or left-ventricular dysfunction: a systematic overview of data from individual patients. Lancet 2000;355:1575-1581.

19. Swedberg K, Komajda M, Böhm M, Borer JS, Ford I, Dubost-Brama A, Lerebours G, Tavazzi L, . Ivabradine and outcomes in chronic heart failure (SHIFT): a randomised placebo-controlled study. Lancet 2010;376:875-885.

20. McMurray JJV, Solomon SD, Inzucchi SE, Gong J, Lefkowitz MP, Rizkala AR, Rouleau JL, Shi VC, Solomon SD, Swedberg K, Zile. Dapagliflozin in patients with heart failure and reduced ejection fraction. N Engl J Med 2019;381:1995-2008.

21. Armstrong PW, Pieske B, Anstrom KJ, Ezekowitz J, Hernandez AF, Butler J, Lam CSP, Ponikowski P, Voors AA, Jia G, McNulty SE, Patel MJ, Roessig L, Koglin J, O'Connor CM. Vericiguat in patients with heart failure and reduced ejection fraction. N Engl J Med 2020;382:1883-1893.

22. Mirowski M, Reid PR, Mower MM, Watkins L, Gott VL, Schauble JF, Langer A, Heilman MS, Kolenik SA, Fischell RE, Weisfeldt ML. Termination of malignant ventricular arrhythmias with an implanted automatic defibrillator in human beings. N Engl J Med 1980;303:322-324.

23. Moss AJ, Jackson Hall W, Cannom DS, Daubert JP, Higgins SL, Klein H, Levine $J$ H, Saksena S, Waldo AL, Wilber D, Brown MW, Heo M. Improved survival with an implanted defibrillator in patients with coronary disease at high risk for ventricular arrhythmia. N Engl J Med 1996;335:1933-1940.

24. McAnulty J, Halperin B, Kron J, Larsen G, Rait M, Swenson R, Floreck R, Marchant C, Hamlin M, Heywood G, Friedman P, Stevenson W, Swat M, Ganz L, Sweeney M, Shea J, Steinberg J, Ehlert F, Zelenkofstke S, Menchavez-Tan E, De Stefano M, Brown G, Karagounis L, Crandall B, Osborn J, Rawling D, Summers K, Jacobsen M, Herre J, Bernsteim R, Klevan L, Cannom D, Bhandari A, Lerman R, Firth B, Klein R, Freedman RR, Marks M, Delahunty M, Spratt C, Marinchak R, Rials S, Kowey P, Fillart R, Hernandez M, Scher D, Zukerman L, Farrell S, Cross J, Shewchjik J, Epstein A, Cooper R, Dailey R, Dailey S, Kay G, Plumb V, Bubien R, Knotts-Dolson S, McKenna P, Tidwell C, Kim S, Fisher J, Ferrick K, Gross J, Ben-Zur U, Durkin J, Ferrick A, Beckman K, McClelland J,Gonzalez M, Widman L, Lane R, Deaton T, Foster J, Straughan G, Wade L, Brodsky M, Allen B, Ehrlich S, Wolff L, Mcari-Hinson M, Coromilas J, Bigger J, Livelli FJ, Reiffel J, Hickey K, Akiyama T, Daubert J, Kim C, Switzer D, Pande P, Flynn D, Keller M, Ocampo C, Wahl K, Vogt J, Kutalek S, Hessen S, Movsowitz C. A comparison of antiarrhythmic-drug therapy with implantable defibrillators in patients resuscitated from near-fatal ventricular arrhythmias. N Engl J Med 1997;337:1576-1583.

25. Buxton AE, Lee KL, Fisher JD, Josephson ME, Prystowsky EN, Hafley G. A randomized study of the prevention of sudden death in patients with coronary artery disease. N Engl J Med 1999;341:1882-1890.

26. Connolly SJ, Gent M, Roberts RS, Dorian P, Roy D, Sheldon RS, Mitchell LB, Green MS, Klein GJ, O'Brien B. Canadian Implantable Defibrillator Study (CIDS): a randomized trial of the implantable cardioverter defibrillator against amiodarone. Circulation 2000;101:1297-1302.

27. Kuck KH, Cappato R, Siebels J, Rüppel R. Randomized comparison of antiarrhythmic drug therapy with implantable defibrillators in patients resuscitated from cardiac arrest: the Cardiac Arrest Study Hamburg (CASH). Circulation 2000; 102:748-754.

28. Connolly S. Meta-analysis of the implantable cardioverter defibrillator secondary prevention trials. Eur Heart J 2000;21:2071-2078.
29. Moss AJ, Zareba W, Jackson Hall W, Klein H, Wilber DJ, Cannom DS, Daubert JP, Higgins SL, Brown MW, Andrews ML. Prophylactic implantation of a defibrillator in patients with myocardial infarction and reduced ejection fraction. N Engl J Med 2002;346:877-883.

30. Bristow MR, Saxon LA, Boehmer J, Krueger S, Kass DA, De Marco T, Carson P, DiCarlo L, DeMets D, White BG, DeVries DW, Feldman AM. Cardiac-resynchronization therapy with or without an implantable defibrillator in advanced chronic heart failure. N Engl J Med 2004;350:2140-2150.

31. Moss AJ, Hall WJ, Cannom DS, Klein H, Brown MW, Daubert JP, Estes NAM, Foster E, Greenberg H, Higgins SL, Pfeffer MA, Solomon SD, Wilber D, Zareba W, Desai P, Wiggins S, Greer G, Beau S, Curnis A, Katz A, Cook J, McPherson C, Rozmus G, Switzer D, Stone J, Ludmer P, Colavita P, Tomassoni G, Crevey B, Nair G, Saliba W, Corbisiero R, Gilliam F, Hranitzky P, Rashtian M, Giudici M, Thomsen P, Clyne C, Pena E, Lessmeier T, Schuger C, Vogt J, Kacet S, Almendral J, Quesada A, Kautzner J, Padeletti L, Delnoy P, Goel S, Berger R, Pitschner H, Martin D, Kfoury A, Klein S, Levin V, Schalij M, Chow T, Chung E, Greenberg Y, Lemke B, Singh J, Rea R, Gold M, Guttigoli A, Adler A, Singer I, Shinn T, Guarnieri T, Casey C, Naccarelli G, Gornick C, Thibault B, Ackerman S, Turk K, Hunter N, Jentzer J, Bartlett T, Glascock D, Tamirisa K, Goldberger J, Coman J, Sandler D, Malik R, Nair L, O'Neill P, Sharma A, Brodine W, Kargul W, Porter M, Merkely B, Onufer J, Eldar M, Gottipaty V, Pires L, Wilson D, Arshad A, Fischer A, Mollerus M, Dixon M, Clair W, Wang P, Cox M, Viskin S, Greenspon A, Thakur R, Link M, Goette A, Duru F, Parker J, Stambler B, Meine M, Badhwar N, Olgin J, Knight B, Attari M, Berenbom L, Shorofsky S, Pelosi F, Mounsey J, Sanders W, Barrington W, Huang D, Saxon L, DiMarco J, Merillat J, Bajaj R, Margolis D, Ewald G, Morgan J, Finta B, Haines D, Oakes D, Pearson T, Richeson F, Pomerantz R, Goldstein R, Haigney M, Krone R, Dwyer E, Kukin M, Lichstein E, Beck C, McNitt S, Zhang H, Bausch J, Wang H, Andrews M, Barber D, Buermann R, Cermak P, Kremer K, Moll J, Oberer A, Palmmontalbano L, Perkins E, Pyykkonen k, Ramsell D. Cardiac-resynchronization therapy for the prevention of heart-failure events. N Engl J Med 2009;361:1329-1338.

32. Hohnloser SH, Kuck KH, Dorian P, Roberts RS, Hampton JR, Hatala R, Fain E, Gent M, Connolly SJ. Prophylactic use of an implantable cardioverterdefibrillator after acute myocardial infarction. N Engl J Med 2004;351:2481-2488.

33. Steinbeck G, Andresen D, Seidl K, Brachmann J, Hoffmann E, Wojciechowski D, Kornacewicz-Jach Z, Sredniawa B, Lupkovics G, Hofgärtner F, Lubinski A, Rosenqvist M, Habets A, Wegscheider K, Senges J. Defibrillator implantation early after myocardial infarction. N Engl J Med 2009;361:1427-1436.

34. Khan SU, Ghimire S, Talluri S, Rahman H, Khan MU, Nasir F, Kaluski E. Implantable cardioverter defibrillator in nonischemic cardiomyopathy: a systematic review and meta-analysis. J Arrhythm 2018;34:4-10.

35. Køber L, Thune JJ, Nielsen JC, Haarbo J, Videbæk L, Korup E, Jensen G, Hildebrandt P, Steffensen FH, Bruun NE, Eiskjær H, Brandes A, Thøgersen AM, Gustafsson F, Egstrup K, Videbæk R, Hassager C, Svendsen JH, Høfsten DE, Torp-Pedersen C, Pehrson S. Defibrillator implantation in patients with nonischemic systolic heart failure. N Engl J Med 2016;375:1221-1230.

36. Boriani G, Malavasi VL. Extending survival by reducing sudden death with implantable cardioverter-defibrillators: a challenging clinical issue in nonischaemic and ischaemic cardiomyopathies. Eur J Heart Fail 2018;20:420-426.

37. Boriani G, Berti E, Belotti LMB, Biffi M, De Palma R, Malavasi VL, Bottoni N, Rossi L, De Maria E, Mantovan R, Zardini M, Casali E, Marconi M, Bandini A, Tomasi C, Boggian G, Barbato G, Toselli T, Zennaro M, Sassone B. Cardiac device therapy in patients with left ventricular dysfunction and heart failure: 'realworld' data on long-term outcomes (mortality, hospitalizations, days alive and out of hospital). Eur J Heart Fail 2016;18:693-702.

38. Boriani G, Malavasi VL. Patient outcome after implant of a cardioverter defibrillator in the 'real world': the key role of co-morbidities. Eur J Heart Fail 2017;19. 387-390.

39. Ruschitzka F, Abraham WT, Singh JP, Delurgio DB, Leon AR, Loh E, Kocovic DZ, Packer M, Clavell AL, Hayes DL, Ellestad M, Trupp RJ, Underwood J, Pickering F, Truex C, McAtee P, Messenger J. Cardiac-resynchronization therapy in heart failure with a narrow QRS complex. N Engl J Med 2013;369:1395-1405.

40. Abraham WT, Fisher WG, Smith AL, Smith AL, Leon AR, Lieberman R, Wilkoff B, Canby RC, Schroeder JS, Liem LB, Hall S, Wheelan K. Cardiac resynchronization in chronic heart failure. N Engl J Med 2002;346:1845-1853.

41. Young JB, Abraham WT, Smith AL, Leon AR, Lieberman R, Wilkoff B, Canby RC, Schroeder JS, Liem LB, Hall S, Wheelan K.. Combined cardiac resynchronization and implantable cardioversion defibrillation in advanced chronic heart failure: the MIRACLE ICD trial. J Am Med Assoc 2003;289:2685-2694.

42. Higgins SL, Hummel JD, Niazi IK, Giudici MC, Worley SJ, Saxon LA, Boehmer JP, Higginbotham MB, De Marco T, Foster E, Yong PG. Cardiac resynchronization therapy for the treatment of heart failure in patients with intraventricular conduction delay and malignant ventricular tachyarrhythmias. J Am Coll Cardiol 2003; 42:1454-1459.

43. Abraham WT, Young JB, León AR, Adler S, Bank AJ, Hall SA, Lieberman R, Liem LB, O'Connell JB, Schroeder JS, Wheelan KR. Effects of cardiac resynchronization 
on disease progression in patients with left ventricular systolic dysfunction, an indication for an implantable cardioverter-defibrillator, and mildly symptomatic chronic heart failure. Circulation 2004;110:2864-2868.

44. Cleland JGF, Daubert JC, Erdmann E, Adler S, Bank AJ, Hall SA, Lieberman R, Liem LB, O'Connell JB, Schroeder JS, Wheelan KR. The effect of cardiac resynchronization on morbidity and mortality in heart failure. N Engl J Med 2005;352: 1539-1549.

45. Linde C, Abraham WT, Gold MR, St. John Sutton M, Ghio S, Daubert C . Randomized trial of cardiac resynchronization in mildly symptomatic heart failure patients and in asymptomatic patients with left ventricular dysfunction and previous heart failure symptoms. J Am Coll Cardiol 2008;52:1834-1843.

46. Tang ASL, Wells GA, Talajic M, Arnold MO, Sheldon R, Connolly S, Hohnloser SH, Nichol G, Birnie DH, Sapp JL, Yee R, Healey JS, Rouleau JL, Ignaszewski A, Dorian P, Haddad H, Newman D, Howlett J, Mitchell LB, Roberts R, Teo K, Gillis A, Newton G, Kerr FP, Gula L, Tung S, Froeschl M, Froeschl S, Swiggum E, Mielniczuk L, Smith S, Hessian R, Fodor G, Vuurmas T, Sterns L, Gardner M, Thibault B, Parkash R, Basta M, Sivakumaran S, Green M, Nery P, Essebag V, Higginson L, Sidhu K, McKee G, Ha A, Theoret-Patrick P, Yetisir E, Luce M, Morin C, Tran ML, Ryan J, Williams K, Gagne L, Lemery R, Gollob M, Posan E, Keren A, Redpath C, Davis D, Melniczuk L, Carlin L, Ewart G, Baker A, MacDonald K, Dunne R, Fleming R, Skanes AC, Klein GJ, Krahn AD, Gray C, Jackson S, Rajda M, Giddens K, Carroll L, Fearon A, Exner DV, Kavanagh KM, Gillis AM, Duff HJ, Isaac DL, Wyse DG, Schroeder K, Ramadan D, Cassidy P, Ellis L, Dorestijn P, Sorensen S, Koshman M, Doucet A, Morillo CA, Nair GM, Long L, Malcolm V, Meyer W, Carroll S, Long L, Kimber S, Pantano A, Cujec B, Gulamhusein S, Chan M, Jones A, Paradon K, Mulcahey C, Haykowsk L, van Schaik A, Scott I, Dubuc M, Gagné P, Guerra PG, Khairy P, Macle L, Roy D, Aubin D, Lemarbre F, Simard E, Leather R, Novak P, McNish H, Green A, Bastell M, Topham P, Goethe JW, Duray G, Israel C, Coutu B, Costi P, De Guise M, Greiss I, Lacombe P, Laramee P, Raymond JM, Bergeron M, Denis I, Roby N, Kerr C, Yeung-Lai-Wah J, Honeyman C, Shepherd S, Simpson C, Abdollah H, Redfearn D, Barnachuk A, Veenhuyzen G, McCans J, Fair S, Staples P, Philippon F, O'Hara G, Molin F, Champagne J, Blier L, Gilbert M, Nault I, Sarrazin JF, Charbonneau L, Wulfhart Z, Khaykin Y, Verma A, Tsang B, Chun R, Symmes J, Srivamadevan M, Thangaroopan M, Hacker P, Patterson S, Nath A, Winger K, Beardsall M, Kus T, Frenette M, Hadjis T, Sturmer M, Becker G, Langlois A, Fortier C, Sami M, Giannetti N, Coutu I, Barber C, Rinne C, Lowery D, Janzen I, Williams J, Stobie P, Anderson H, Di Camillo C, Ferguson L, Jenkinson L, Crystal E, Lashevsky I, Lau C, Daoulah A, Calton R, Pekar A, Letvin E, Vecchio J, Lukomsky M, Yuen V, Lakhanpal M, Connors S, Furey M, Fagan S, Matthews J, Constantine M, Power K, Mangat I, Pinter A, Korley V, Ahmad K, O'Donnell S, Allan K, Kowalewski M, Darling D, Erdogan A, Franzen W, Greiss H, SteenMüller MK, Sanders P, Young G, Stiles M, John B, Leong D, Cehic D, Shashidhar, Dimitri H, Mitchell AM, Maxwell V, Nicholls V, Ayala Parades F, Roux JF, Jean C, Lavallee L, Cameron D, Parker J, Hill A, Abraham L, Weiss C, Himmrich E, Hink HU, Mollnau H, Willems R, Heidbüchel H, Huybrechts W, Nuyens D, Rossenbacker T, Van Cleemput J, Vanhaecke J, Droogné W, Ramdat Misier AR, Beukema WP, Delnoy PP, Elvan A, Smit JJ, Toal S, Douglas G, Searles G, Fitzgerald F, Collings E, Seidl K, Kleemann T, Strauss U, Geller JC, Can LH, Hasdemir C, Labonté R, Juma Z, Peterson T, Beausoleil B, Lai C,Nigro F, Maguire B, Fox G. Cardiac-resynchronization therapy for mild-to-moderate heart failure. N Engl J Med 2010;363:2385-2395.

47. Curtis AB, Worley SJ, Adamson PB, Chung ES, Niazi I, Sherfesee L, Shinn T, Sutton MSJ. Biventricular pacing for atrioventricular block and systolic dysfunction. N Engl J Med 2013;368:1585-1593.

48. Boriani G, Ziacchi M, Nesti M, Battista A, Placentino F, Malavasi VL, Diemberger I, Padeletti L. Cardiac resynchronization therapy: how did consensus guidelines from Europe and the United States evolve in the last 15years? Int J Cardiol 2018; 261:119-129.

49. Brignole M, Auricchio A, Baron-Esquivias G, Bordachar P, Boriani G, Breithardt O-A, Cleland J, Deharo J-C, Delgado V, Elliott PM, Gorenek B, Israel CW, Leclercq C, Linde C, Mont L, Padeletti L, Sutton R, Vardas PE, Zamorano JL, Achenbach S, Baumgartner H, Bax J], Bueno H, Dean V, Deaton C, Erol C, Fagard R, Ferrari R, Hasdai D, Hoes AW, Kirchhof P, Knuuti J, Kolh P, Lancellotti P, Linhart A, Nihoyannopoulos P, Piepoli MF, Ponikowski P, Sirnes PA, Tamargo JL, Tendera M, Torbicki A, Wijns W, Windecker S, Kirchhof P, BlomstromLundqvist C, Badano LP, Aliyev F, Bansch D, Baumgartner $H$, Bsata W, Buser $P$, Charron P, Daubert J-C, Dobreanu D, Faerestrand S, Hasdai D, Hoes AW, Le Heuzey J-Y, Mavrakis H, McDonagh T, Merino JL, Nawar MM, Nielsen JC, Pieske B, Poposka L, Ruschitzka F, Tendera M, Van Gelder IC, Wilson CM, Authors/ Task Force Members. ESC Guidelines on cardiac pacing and cardiac resynchronization therapy: the Task Force on cardiac pacing and resynchronization therapy of the European Society of Cardiology (ESC). Developed in collaboration with the European Heart Rhythm Association . Europace 2013;15:1070-1118.

50. Goette A, Auricchio A, Boriani G, Braunschweig F, Terradellas JB, Burri H, Camm AJ, Crijns H, Dagres N, Deharo JC, Dobrev D, Hatala R, Hindricks G,
Hohnloser SH, Leclercq C, Lewalter T, Lip GYH, Merino JL, Mont L, Prinzen F, Proclemer A, Pürerfellner H, Savelieva I, Schilling R, Steffel J, Van Gelder IC, Zeppenfeld K, Zupan I, Heidbüchel H, Boveda S, Defaye P, Brignole M, Chun J, Guerra Ramos JM, Fauchier L, Svendsen JH, Traykov VB, Heinzel FR, ESC Scientific Document Group. EHRA White Paper: knowledge gaps in arrhythmia management-status 2019. Europace 2019;21:993-994.

51. Schrage B, Uijl A, Benson L, Westermann D, Ståhlberg M, Stolfo D, Dahlström $U$, Linde C, Braunschweig F, Savarese G. Association between use of primaryprevention implantable cardioverter-defibrillators and mortality in patients with heart failure: a prospective propensity score-matched analysis from the Swedish Heart Failure Registry. Circulation 2019;140:1530-1539.

52. Zabel R, Willems A, Lubinski A, Bauer J, Brugada D, Conen P, Flevari G, Hasenfuß M, Svetlosak HV, Huikuri M, Malik N, Pavlović G, Schmidt R, Sritharan S, Schlögl J, Szavits-Nossan V, Traykov AE, Tuinenburg SN, Willich M, Harden T, Friede JH, Svendsen C, Sticherling B, Merkely B, Merkely P, Perge Z, Sallo G, Szeplaki N, Szegedi KV, Nagy M, Zabel L, Lüthje S, Schlögl R, Sritharan H, Haarmann L, Bergau J, Seegers G, Hasenfuß P, Munoz-Exposito T, Tichelbäcker A, Kirova G, Hasenfu $\beta$ T, Friede M, Zabel S, Schlögl T, Friede M, Harden M, Malik K, Hnatkova MA, Vos SN, Willich T, Reinhold R, Willems B, Vandenberk M, Klinika J, Szavits-Nossan L, Rotkvić P, Flevari A, Katsimardos D, Katsaras R, Hatala M, Svetlosak A, Lubinski T, Kuczejko J, Hansen C, Sticherling D, Conen N, Pavlović Š, Manola O, Vinter I, Benko A, Tuinenburg D, Sprenkeler A, Smoczynska MA, Vos A, Bauer C, Meyer-Zürn C, Eick JH, Svendsen J, Brugada E, Arbelo G, Kaliska J, Martinek G, Schmidt M, Dommasch A, Steger S, Kääb A, Bauer MF, Sinner KD, Rizas W, Hamm V, Traykov I, Cygankiewicz P, Ptaszyński K, Kaczmarek I, Poddebska S, lovev T, Novotný M, Kozak H, Huikuri T, Kenttä A, Pelli JD, Kasprzak D, Qavoq S, Brusich E, Avdovic M, Klasan J, Galuszka M, Taborsky V, Velchev R, Dissmann T, Shalganov P, Guzik T, Krauze D, Bimmel C, Lieberz K, Ludwigsburg S, Stefanow N, Rüb C, Wolpert J, Seegers LS, Meier S, Behrens Z, Jurisic F, Braunschweig F, Blaschke B, Pieske Z, Bakotic A, Anic K, Weiden RHG, Schwinger P, Platonov G, Grönefeld T. Klingenheben. Clinical effectiveness of primary prevention implantable cardioverter-defibrillators: results of the EU-CERT-ICD controlled multicentre cohort study. Eur Heart J. 2020. doi: 10.1093/eurheartj/ehaa226.

53. Kutyifa V, Moss AJ, Klein H, Biton Y, McNitt S, MacKecknie B, Zareba W, Goldenberg I. Use of the wearable cardioverter defibrillator in high-risk cardiac patients data from the prospective registry of patients using the wearable cardioverter defibrillator (WEARIT-II registry). Circulation 2015;132:1613-1619.

54. Olgin JE, Pletcher MJ, Vittinghoff E, Wranicz J, Malik R, Morin DP, Zweibel S, Buxton AE, Elayi CS, Chung EH, Rashba E, Borggrefe M, Hue TF, Maguire C, Lin F, Simon JA, Hulley S, Lee BK. Wearable cardioverter-defibrillator after myocardial infarction. N Engl J Med 2018;379:1205-1215.

55. Olgin JE, Lee BK, Vittinghoff E, Morin DP, Zweibel S, Rashba E, Chung EH, Borggrefe M, Hulley S, Lin F, Hue TF, Pletcher MJ. Impact of wearable cardioverter-defibrillator compliance on outcomes in the VEST trial: as-treated and per-protocol analyses. J Cardiovasc Electrophysiol 2020;31:1009-1018.

56. McMurray JJV, Packer M, Desai AS, Gong J, Lefkowitz MP, Rizkala AR, Rouleau JL, Shi VC, Solomon SD, Swedberg K, Zile MR. Angiotensin-neprilysin inhibition versus enalapril in heart failure. N Engl J Med 2014;371:993-1004.

57. Desai AS, McMurray JJV, Packer M, Swedberg K, Rouleau JL, Chen F, Gong J, Rizkala AR, Brahimi A, Claggett B, Finn PV, Hartley LH, Liu J, Lefkowitz M, Shi V, Zile MR, Solomon SD. Effect of the angiotensin-receptor-neprilysin inhibitor LCZ696 compared with enalapril on mode of death in heart failure patients. Eur Heart J 2015;36:1990-1997.

58. Packer M, McMurray JJV, Desai AS, Gong J, Lefkowitz MP, Rizkala AR, Rouleau JL, Shi VC, Solomon SD, Swedberg K, Zile M, Andersen K, Arango JL, Arnold JM, Bělohlávek J, Böhm M, Boytsov S, Burgess LJ, Cabrera W, Calvo C, Chen C-H, Dukat A, Duarte YC, Erglis A, Fu M, Gomez E, Gonzàlez-Medina A, Hagège AA, Huang J, Katova T, Kiatchoosakun S, Kim K-S, Kozan Ö, Llamas EB, Martinez F, Merkely B, Mendoza I, Mosterd A, Negrusz-Kawecka M, Peuhkurinen K, Ramires FJA, Refsgaard J, Rosenthal A, Senni M, Sibulo AS, Silva-Cardoso J, Squire IB, Starling RC, Teerlink JR, Vanhaecke J, Vinereanu D, Wong RC-C. Angiotensin receptor neprilysin inhibition compared with enalapril on the risk of clinical progression in surviving patients with heart failure. Circulation 2015;131:54-61.

59. Boriani G, Fauchier L, Aguinaga L, Beattie JM, Blomstrom Lundqvist C, Cohen A Dan GA, Genovesi S, Israel C, Joung B, Kalarus Z, Lampert R, Malavasi VL, Mansourati J, Mont L, Potpara T, Thornton A, Lip GYH, Gorenek B, Marin F, Dagres N, Ozcan EE, Lenarczyk R, Crijns HJ, Guo Y, Proietti M, Sticherling C, Huang D, Daubert JP, Pokorney SD, Cabrera Ortega M, Chin A, ESC Scientific Document Group. European Heart Rhythm Association (EHRA) consensus document on management of arrhythmias and cardiac electronic devices in the critically ill and post-surgery patient, endorsed by Heart Rhythm Society (HRS), Asia Pacific Heart Rhythm Society (APHRS), Card. Europace 2019;21:7-8.

60. Dal Canto E, Ceriello A, Rydén L, Ferrini M, Hansen TB, Schnell O, Standl E, Beulens JW. Diabetes as a cardiovascular risk factor: an overview of global trends of macro and micro vascular complications. Eur J Prev Cardiol 2019;26:25-32. 
61. Piepoli MF, Hoes AW, Agewall S, Albus C, Brotons C, Catapano AL, Cooney MT, Corrà U, Cosyns B, Deaton C, Graham I, Hall MS, Hobbs FDR, Løchen M-L, Löllgen H, Marques-Vidal P, Perk J, Prescott E, Redon J, Richter DJ, Sattar N, Smulders Y, Tiberi M, van der Worp HB, van Dis I, Verschuren WMM, De Backer G, Roffi M, Aboyans V, Bachl N, Bueno H, Carerj S, Cho L, Cox J, De Sutter J, Egidi G, Fisher M, Fitzsimons D, Franco OH, Guenoun M, Jennings C, Jug B, Kirchhof P, Kotseva K, Lip GYH, Mach F, Mancia G, Bermudo FM, Mezzani A, Niessner A, Ponikowski P, Rauch B, Rydén L, Stauder A, Turc G, Wiklund O, Windecker S, Zamorano JL. 2016 European Guidelines on cardiovascular disease prevention in clinical practice the Sixth Joint Task Force of the European Society of Cardiology and Other Societies on Cardiovascular Disease Prevention in Clinical Practice (constituted by representatives of 10 societies and by invited experts) Developed with the special contribution of the European Association for Cardiovascular Prevention \& Rehabilitation (EACPR). Eur J Prev Cardiol 2016; 23:NP1-NP96.

62. Okumura N, Jhund PS, Gong J, Lefkowitz MP, Rizkala AR, Rouleau JL, Shi VC, Swedberg K, Zile MR, Solomon SD, Packer M, Mcmurray JJV. Effects of sacubitril/ valsartan in the PARADIGM-HF trial (Prospective Comparison of ARNI with ACEI to Determine Impact on Global Mortality and Morbidity in Heart Failure) according to background therapy. Circ Heart Fail 2016;9. doi: 10.1161/CIRCHEARTFAILURE.116.003212.

63. de Diego C, González-Torres L, Núñez JM, Centurión Inda R, Martin-Langerwerf DA, Sangio AD, Chochowski P, Casasnovas P, Blazquéz JC, Almendral J. Effects of angiotensin-neprilysin inhibition compared to angiotensin inhibition on ventricular arrhythmias in reduced ejection fraction patients under continuous remote monitoring of implantable defibrillator devices. Heart Rhythm 2018;15: 395-402.

64. Martens P, Nuyens D, Rivero-Ayerza M, Van Herendael H, Vercammen J, Ceyssens W, Luwel E, Dupont M, Mullens W. Sacubitril/valsartan reduces ventricular arrhythmias in parallel with left ventricular reverse remodeling in heart failure with reduced ejection fraction. Clin Res Cardiol 2019;108: 1074-1082.

65. Hubers SA, Brown NJ. Combined angiotensin receptor antagonism and neprilysin inhibition. Circulation 2016;133:1115-1124.

66. von Lueder TG, Wang BH, Kompa AR, Huang L, Webb R, Jordaan P, Atar D, Krum H. Angiotensin receptor neprilysin inhibitor LCZ696 attenuates cardiac remodeling and dysfunction after myocardial infarction by reducing cardiac fibrosis and hypertrophy. Circ Heart Fail 2015;8:71-78.

67. Schneider PM, Pellegrini CN, Wang Y, Fein AS, Reynolds MR, Curtis JP, Masoudi FA, Varosy PD. Prevalence of guideline-directed medical therapy among patients receiving cardiac resynchronization therapy defibrillator implantation in the national cardiovascular data registry during the years 2006 to 2008. Am J Cardiol 2014;113:2052-2056.

68. Witt CT, Kronborg MB, Nohr EA, Mortensen PT, Gerdes C, Nielsen JC. Optimization of heart failure medication after cardiac resynchronization therapy and the impact on long-term survival. Eur Hear J - Cardiovasc Pharmacother 2015; 1:182-188.

69. Roth GA, Poole JE, Zaha R, Zhou W, Skinner J, Morden NE. Use of guidelinedirected medications for heart failure before cardioverter-defibrillator implantation. J Am Coll Cardiol 2016;67:1062-1069.

70. Burri H, da Costa A, Quesada A, Ricci R Pietro, Favale S, Clementy N, Boscolo G, Villalobos FS, Mangoni di S. Stefano L, Sharma V, Boriani G. Risk stratification of cardiovascular and heart failure hospitalizations using integrated device diagnostics in patients with a cardiac resynchronization therapy defibrillator. Europace 2018;20:e69-e77.

71. Boehmer JP, Hariharan R, Devecchi FG, Smith AL, Molon G, Capucci A, An Q, Averina V, Stolen CM, Thakur PH, Thompson JA, Wariar R, Zhang Y, Singh JP. A multisensor algorithm predicts heart failure events in patients with implanted devices: results from the MultiSENSE study. JACC Heart Fail 2017;5:216-225.

72. Capucci A, Santini L, Favale S, Pecora D, Petracci B, Calò L, Molon G, Cipolletta L, Bianchi V, Schirripa V, Santobuono V, La Greca C, Campari M, Valsecchi S, Ammirati F, D'Onofrio A. Preliminary experience with the multisensor HeartLogic algorithm for heart failure monitoring: a retrospective case series report. ESC Heart Fail 2019;6:308-318.

73. DeFilippis EM, Butler J, Vaduganathan M. Waiting period before implantable cardioverter-defibrillator implantation in newly diagnosed heart failure with reduced ejection fraction: a window of opportunity. Circ Heart Fail 2017;10. doi: 10.1161/CIRCHEARTFAILURE.117.004478.

74. Zecchin M, Merlo M, Pivetta A, Barbati G, Lutman C, Gregori D, Serdoz LV, Bardari S, Magnani S, Di Lenarda A, Proclemer A, Sinagra G. How can optimization of medical treatment avoid unnecessary implantable cardioverterdefibrillator implantations in patients with idiopathic dilated cardiomyopathy presenting with 'SCD-HeFT Criteria?' Am J Cardiol 2012;109:729-735.

75. Perera K, Ademi Z, Liew D, Zomer E. Sacubitril-valsartan versus enalapril for acute decompensated heart failure: a cost-effectiveness analysis. Eur J Prev Cardiol 2019;204748731987895. doi: 10.1177/2047487319878953.
76. D’Onofrio A, Palmisano P, Rapacciuolo A, Ammendola E, Calò L, Ruocco A, Bianchi V, Maresca F, Del Giorno G, Martino A, Mauro C, Campari M, Valsecchi $S$, Accogli M. Effectiveness of a management program for outpatient clinic or remote titration of beta-blockers in CRT patients: the RESTORE study. Int J Cardiol 2017;236:290-295

77. Kapelios C), Lainscak M, Savarese G, Laroche C, Seferovic P, Ruschitzka F, Coats A, Anker SD, Crespo-Leiro MG, Filippatos G, Piepoli MF, Rosano G, Zanolla L, Aguiar C, Murin J, Leszek P, McDonagh T, Maggioni AP, Lund LH, Auer J, Ablasser K, Fruhwald F, Dolze T, Brandner K, Gstrein S, Poelzl G, Moertl D, Reiter S, Podczeck-Schweighofer A, Muslibegovic A, Vasilj M, Fazlibegovic E, Cesko M, Zelenika D, Palic B, Pravdic D, Cuk D, Vitlianova K, Katova T, Velikov T, Kurteva T, Gatzov P, Kamenova D, Antova M, Sirakova V, Krejci J, Mikolaskova M, Spinar J, Krupicka J, Malek F, Hegarova M, Lazarova M, Monhart Z, Hassanein M, Sobhy M, El Messiry F, El Shazly AH, Elrakshy Y, Youssef A, Moneim AA, Noamany M, Reda A, Abdel Dayem TK, Farag N, Ibrahim Halawa S, Abdel Hamid M, Said K, Saleh A, Ebeid H, Hanna R, Aziz R, Louis O, Enen MA, Ibrahim BS, Nasr G, Elbahry A, Sobhy H, Ashmawy M, Gouda M, Aboleineen W, Bernard Y, Luporsi P, Meneveau N, Pillot M, Morel M, Seronde MF, Schiele F, Briand F, Delahaye F, Damy T, Eicher JC, de Groote P, Fertin M, Lamblin N, Isnard R, Lefol C, Thevenin S, Hagege A, Jondeau G, Logeart D, Le Marcis V, Ly JF, Coisne D, Lequeux B, Le Moal V, Mascle S, Lotton P, Behar N, Donal E, Thebault C, Ridard C, Reynaud A, Basquin A, Bauer F, Codjia R, Galinier M, Tourikis P, Stavroula M, Tousoulis D, Stefanadis C, Chrysohoou C, Kotrogiannis I, Matzaraki V, Dimitroula T, Karavidas A, Tsitsinakis G, Kapelios C, Nanas J, Kampouri H, Nana E, Kaldara E, Eugenidou A, Vardas P, Saloustros I, Patrianakos A, Tsaknakis T, Evangelou S, Nikoloulis N, Tziourganou H, Tsaroucha A, Papadopoulou A, Douras A, Polgar L, Merkely B, Kosztin A, Nyolczas N, Csaba Nagy A, Halmosi R, Elber J, Alony I, Shotan A, Vazan Fuhrmann A, Amir O, Romano S, Marcon S, Penco M, Di Mauro M, Lemme E, Carubelli V, Rovetta R, Metra M, Bulgari M, Quinzani F, Lombardi C, Bosi S, Schiavina G, Squeri A, Barbieri A, Di Tano G, Pirelli S, Ferrari R, Fucili A, Passero T, Musio S, Di Biase M, Correale M, Salvemini G, Brognoli S, Zanelli E, Giordano A, Agostoni P, Italiano G, Salvioni E, Copelli S, Modena MG, Reggianini L, Valenti C, Olaru A, Bandino S, Deidda M, Mercuro G, Cadeddu Dessalvi C, Marino PN, Di Ruocco MV, Sartori C, Piccinino C, Parrinello G, Licata G, Torres D, Giambanco S, Busalacchi S, Arrotti S, Novo S, Inciardi RM, Pieri P, Chirco PR, Ausilia Galifi M, Teresi G, Buccheri D, Minacapelli A, Veniani M, Frisinghelli A, Priori SG, Cattaneo S, Opasich C, Gualco A, Pagliaro M, Mancone M, Fedele F, Cinque A, Vellini M, Scarfo I, Romeo F, Ferraiuolo F, Sergi D, Anselmi M, Melandri F. Sacubitril/valsartan eligibility and outcomes in the ESC-EORP-HFA Heart Failure Long-Term Registry: bridging between European Medicines Agency/Food and Drug Administration label, the PARADIGM-HF trial, ESC guidelines, and real world. Eur J Heart Fail 2019;21:1383-1397.

78. Adabag S, Patton KK, Buxton AE, Rector TS, Ensrud KE, Vakil K, Levy WC, Poole JE. Association of implantable cardioverter defibrillators with survival in patients with and without improved ejection fraction secondary analysis of the sudden cardiac death in heart failure trial. JAMA Cardiol 2017;2:767-774.

79. Friedman DJ, Fudim M, Overton R, Shaw LK, Patel D, Pokorney SD, Velazquez EJ, Al-Khatib SM. The relationship between baseline and follow-up left ventricular ejection fraction with adverse events among primary prevention ICD patients. Am Heart J 2018;201:17-24.

80. Zhang Y, Guallar E, Blasco-Colmenares E, Butcher B, Norgard S, Nauffal V, Marine JE, Eldadah Z, Dickfeld T, Ellenbogen KA, Tomaselli GF, Cheng A. Changes in follow-up left ventricular ejection fraction associated with outcomes in primary prevention implantable cardioverter-defibrillator and cardiac resynchronization therapy device recipients. J Am Coll Cardiol 2015;66:524-531.

81. Madhavan M, Waks JW, Friedman PA, Kramer DB, Buxton AE, Noseworthy PA, Mehta RA, Hodge DO, Higgins AY, Webster TL, Witt CM, Cha YM, Gersh BJ. Outcomes after implantable cardioverter-defibrillator generator replacement for primary prevention of sudden cardiac death. Circ Arrhythm Electrophysiol 2016;9. doi:10.1161/CIRCEP.115.003283.

82. Poole JE, Johnson GW, Hellkamp AS, Anderson J, Callans DJ, Raitt MH, Reddy RK, Marchlinski FE, Yee R, Guarnieri T, Talajic M, Wilber DJ, Fishbein DP, Packer DL, Mark DB, Lee KL, Bardy GH. Prognostic importance of defibrillator shocks in patients with heart failure. N Engl J Med 2008;359:1009-1017.

83. Guerra F, Palmisano P, Dell'Era G, et al. Implantable cardioverter-defibrillator programming and electrical storm: results of the OBSERVational registry On long-term outcome of ICD patients (OBSERVO-ICD). Heart Rhythm 2016;13: 1987-1992.

84. Guerra F, Flori M, Bonelli P, Patani F, Capucci A. Electrical storm and heart failure worsening in implantable cardiac defibrillator patients. Europace 2014;17: 247-254.

85. Sarrias A, Bayes-Genis A. Is sacubitril/valsartan (also) an antiarrhythmic drug? Circulation 2018;138:551-553.

86. Braunschweig F, Boriani G, Co-Chair, Bauer A, Hatala R, Herrmann-Lingen C, Kautzner J, Pedersen SS, Pehrson S, Ricci R, Schalij MJ. Management of patients 
receiving implantable cardiac defibrillator shocks Recommendations for acute and long-term patient management. Europace 2010;12:1673-1690.

87. Russo V, Bottino R, Rago A, Papa AA, Liccardo B, Proietti R, Manna V, Golino P, D'Onofrio A, Nigro G. The effect of sacubitril/valsartan on device detected arrhythmias and electrical parameters among dilated cardiomyopathy patients with reduced ejection fraction and implantable cardioverter defibrillator. J Clin Med 2020;9:1111.

88. Guerra F, Palmisano P, Dell'Era G, Ziacchi M, Ammendola E, Pongetti G, Bonelli P, Patani F, Devecchi C, Accogli M, Occhetta E, Nigro G, Biffi M, Boriani G, Capucci A, Cardiac resynchronization therapy and electrical storm: results of the OBSERVational registry on long-term outcome of ICD patients (OBSERVO-ICD). Europace 2018;20: 979-985.

89. Packer M. Compelling first-line drug and device therapies for the prevention of sudden death in patients with chronic heart failure and a reduced ejection fraction who are candidates for an implantable cardioverter-defibrillator. Circ Arrhythm Electrophysiol 2019;12:e007430.

90. Wang Y, Zhou R, Lu C, Chen Q, Xu T, Li D. Effects of the angiotensin-receptor neprilysin inhibitor on cardiac reverse remodeling: meta-analysis. J Am Heart Assoc 2019;8. doi:10.1161/jaha.119.012272.

91. Boriani G, Biffi M, Martignani C, Fallani F, Greco C, Grigioni F, Corazza I, Bartolini P, Rapezzi C, Zannoli R, Branzi A. Cardiac resynchronization by pacing: an electrical treatment of heart failure. Int J Cardiol 2004;94:151-161.

92. Leyva F, Nisam S, Auricchio A. 20 years of cardiac resynchronization therapy. J Am Coll Cardiol 2014;64:1047-1058.

93. Ypenburg C, van Bommel RJ, Borleffs CJW, Bleeker GB, Boersma E, Schalij MJ, Bax J. Long-term prognosis after cardiac resynchronization therapy is related to the extent of left ventricular reverse remodeling at midterm follow-up. J Am Coll Cardiol 2009;53:483-490.
94. Sze E, Samad Z, Dunning A, Campbell KB, Loring Z, Atwater BD, Chiswell K, Kisslo JA, Velazquez EJ, Daubert JP. Impaired recovery of left ventricular function in patients with cardiomyopathy and left bundle branch block. J Am Coll Cardiol 2018;71:306-317.

95. Klersy C, Boriani G, De Silvestri A, Mairesse GH, Braunschweig F, Scotti V, Balduini A, Cowie MR, Leyva F. Effect of telemonitoring of cardiac implantable electronic devices on healthcare utilization: a meta-analysis of randomized controlled trials in patients with heart failure. Eur J Heart Fail 2016;18: 195-204.

96. Santini L, D’Onofrio A, Dello Russo A, Calò L, Pecora D, Favale S, Petracci B, Molon G, Bianchi V, De Ruvo E, Ammirati F, Greca CLa, Campari M, Valsecchi S, Capucci A. Prospective evaluation of the multisensor HeartLogic algorithm for heart failure monitoring . Clin Cardiol 2020. doi:10.1002/clc.23366.

97. Vicent L, Juárez M, Martín I, García J, González-Saldívar H, Bruña V, Devesa C, Sousa-Casasnovas I, Fernández-Avilés F, Martínez-Sellés M. Ventricular arrhythmic storm after initiating sacubitril/valsartan. Cardiology 2018;139: $119-123$.

98. Okutucu S, Oto A. Electrical storm after initiating sacubitril/valsartan: arrhythmic paradox. Cardiology 2019;142:24-25.

99. Gatti M, Antonazzo IC, Diemberger I, De Ponti F, Raschi E. Adverse events with sacubitril/valsartan in the real world: emerging signals to target preventive strategies from the FDA adverse event reporting system. Eur J Prev Cardiol 2020; 204748732091566. doi: 10.1177/2047487320915663.

100. Hübinette C, Lund LH, Gadler F, Ståhlberg M. Awareness of indications for device therapy among a broad range of physicians: a survey study. Europace 2014; 16:1580-1586. 